\title{
Technology Parks versus Science Parks: does the university make the difference?
}

\begin{abstract}
Science and Technology Parks (STPs) has become fairly widespread through the world, although their effect on firms' innovation performance is still a very debated issue. A recent stream in the literature points to heterogeneity of tenants and of parks themselves being a key concept when assessing STPs effect on tenants' performance. An important source of STPs heterogeneity that has been disregarded so far is the degree of university involvement in these parks. At the extremes, there are parks that are owned and managed by universities, and parks with no formal links with a university. We use data from the Community Innovation Survey (CIS) for Spain and a survey of STP park managers to analyse how the degree of involvement of a university in the STP is related to innovation outputs of its tenants and their links with universities. We show that higher involvement of a university in the STP is positively related to the number of patent applications, but negatively related to tenant's innovation sales. In addition, we find no robust evidence that higher involvement of a university in the STP is positively related to the propensity for park firms to cooperate with a university or to purchase external R\&D services from the university.
\end{abstract}

Keywords: Science and Technology Parks; innovation policy; innovation performance; academia-industry relations; universities. 


\section{Introduction}

Science and Technology Parks (STPs) are policy-driven agglomerations (Huang et al., 2012) with management teams actively engaged in fostering the creation and growth of innovative onsite firms (IASP, 2002).

The attention that STPs have attracted among the scientific community has grown alongside the weight that parks have achieved in the technology and innovation policy scenarios in many countries. A census of existing initiatives is not easy, but it is possible to give an idea of the magnitude of the phenomenon. The World Alliance for Innovation (WAINOVA), ${ }^{1}$ states that in 2009 the number of STPs across the world was estimated at 1,500, with the highest concentrations in the US (WAINOVA, 2009), where the phenomenon originated more than 60 years ago at Stanford University, and in Europe.

STPs have fuelled debate among academics, practitioners and policy makers as to their effectiveness as instruments of innovation policy. Some authors question the STP model (e.g. Macdonald, 1987; Massey et al., 1992; Quintas et al., 1992; Hansson et al., 2005) while others claim that STPs provide a supportive environment for firms (e.g. Del Castillo Hermosa and Barroeta, 1998; Siegel et al., 2003a; Hommen et al., 2006) - a debate that has been stoked by empirical work. Some authors find a positive effect of STP location on firms' innovation performance (e.g. Vásquez-Urriago et al., 2014; Squicciarini, 2008, 2009, Siegel et al., 2003b; Yang et al., 2009), while others observe no significant differences between on-park and off-park firms (e.g. Westhead, 1997; Colombo and Delmastro, 2002; Löfsten and Lindelöf, 2002).

This contrasting evidence on the effects of the on-park location for firms may be due to the fact that most of previous studies focus on the homogeneous effects of on-park location. Authors make implicit assumptions that, on the one hand, all firms benefit in the same way from on-park location and, on the other hand, all the parks have the same effects on their tenant firms.

More recently, some authors have questioned these assumptions. Vásquez-Urriago et al., (2016a), Diez-Vial and Fernández-Olmos (2015, 2016), Liberati et al., (2016), and Huang et al., (2012) have begun to consider firm heterogeneity and hypothesize that some firms benefit from STPs location more than others. They analyse the influence of firm characteristics, such as age (Diez-Vial and Fernández-Olmos, 2016 and Liberati et al., 2016), size (Liberati et al., 2016; Vásquez-Urriago et al., 2016a and Huang et al., 2012), internal innovation capability (VásquezUrriago et al., 2016a and Huang et al., 2012) and previous cooperation agreements with universities (Diez-Vial and Fernández-Olmos, 2015), on the benefits of location and conclude that firm characteristics modulate the externalities from particular locations. Liberati et al.

\footnotetext{
${ }^{1}$ Wainova includes 28 of the major STPs and business incubator associations in different countries.
} 
(2016) and Albahari et al. (2016) study the effect of some STP characteristics, such as age, size, geographical area, ownership, sectorial specialization, characteristics of the management team, and services offered to tenants. They find that STP characteristics affect tenants' innovation performance. This new stream of research on STPs points to heterogeneity being a key concept to explain STP effectiveness as an innovation policy tool.

However, this recent literature has not analyzed one very important source of park heterogeneity: the degree of involvement of universities in the park. The importance of universities as external sources of knowledge for firm innovation has been widely recognized since the 1980s (Bozeman, 2000) and emphasized in Etzkowitz and Leydesdorff's (1997) triple helix and by open-innovation (Chesbrough, 2003) approaches. Moreover their traditional role of knowledge producers, universities have been increasingly expected to engage in interactions with industrial and regional partners (Jongbloed et al., 2008), to contribute to innovation and social change - the so called 'third mission' (Gulbrandsen and Slipersaeter, 2007). Universities have seen in STPs an instrument to facilitate commercialization of academic research, to internalize financial returns of academic research (Storey and Tether, 1998b; Link et al., 2007) and to legitimize their knowledge transfer activities related to their commitment to contribute to society (Monck et al., 1988).

The definition given by the International Association of Science Parks (IASP, 2002) states that STPs aim at facilitating and managing flows of knowledge and technology amongst universities, R\&D institutions, companies and markets, and stimulating the creation and growth of innovation-based companies through incubation and spin-off processes. In reality, the different development patterns and wide variety of shareholders and founders of STPs (Phan et al., 2005) have contributed to the formation of very heterogeneous organizations (Westhead, 1997), with an important difference being the degree of involvement of a university in the park. For example, while all STPs in the UK are university initiatives (Westhead and Storey 1995; Siegel et al., 2003a), in most countries (e.g. the US (Link and Scott, 2007), Australia (Phillimore, 1999), China (Wright et al., 2008), Japan (Fukugawa, 2006), France (Chorda, 1996), Portugal (Ratinho and Henriques, 2010), Spain and Italy (Albahari et al., 2013)) the degree of involvement of universities in STPs varies hugely ${ }^{2}$. In broad terms, it is possible to identify two types of STPs: parks in which there is university shareholding, that we may call Science Parks and parks in which the university is not involved in the ownership of the park, that we may call Technology Parks.

\footnotetext{
${ }^{2}$ E.g., Albahari et al. (2013) report that the founders and promoters of $37 \%$ of Italian STPs and $56 \%$ of Spanish STPs do not include a university; Link and Scott (2005) in a sample of 51 American STPs found that $69 \%$ were not operated by a university.
} 
Despite the popularity of STPs around the world and the research attention they have attracted, to our knowledge, there are no empirical studies that investigate the effect of the degree of university involvement in an STP.

The present paper has two main objectives: to fill this gap in the literature by empirically analysing the influence of the degree of involvement of universities in an STP on its tenants' innovation performance, and to analyse how this degree of involvement affects the relationship between tenants and universities.

Our study is based on the Spanish case, which includes parks with a great variety in the degree of university involvement, making it an appropriate context for this investigation.

One important added value of our work is that we use two different data sources: the 2009 Community Innovation Survey (CIS) for Spain (available since 2011), and the Survey 2009 on the Characteristics and Results of Science and Technology Parks conducted by the former Department of Science and Innovation of the Spanish government. More precisely, some recent studies (Diéz-Vial and Fernández-Olmos, 2015, 2016; Montoro-Sánchez et al., 2011) have used CIS data to analyse the influence of STPs. These very valuable works have the limitation that they cannot match firm and park data because the database does not provide the name of the STP in which the firms is located. We were granted access to secured places in the Spanish Institute of Statistic so that we could match firm data with the characteristics of the specific STP in which the firm is located, which is a novelty in studies on STPs with CIS data.

The remainder of this paper is organized as follows. Section 2 reviews the literature, Section 3 provides an overview on the level of development of the STP phenomenon in Spain, Section 4 specifies the empirical framework for the study, Section 5 presents the results and Section 6 concludes and suggests some directions for future research.

\section{Literature review}

\subsection{Technology Parks versus Science Parks}

Technology Parks follow a rationale of spatial proximity (Oerlemans and Meeus, 2005) in which firms may benefit from different types of agglomeration externalities. Specialised parks where most firms belong to the same industry - may provide Marshall-Arrow-Romer and Porter externalities to tenants, while firms in non-specialised parks may take advantage of Jacobs' externalities $^{3}$. Park location allows access to specialized inputs including labour, the benefits derived from knowledge spillovers (Prevezer, 1997), and reduced consumers' search costs

\footnotetext{
${ }^{3}$ For the different types of agglomeration externalities see, e.g., Glaser et al. (1992).
} 
(McCann and Folta, 2008). Spatial proximity is believed to be important for innovation because smaller geographical distances facilitate the establishment of links (Hervas-Oliver and AlborsGarrigos, 2009) and the transfer of knowledge, especially tacit knowledge (Howells, 2002), which tends to be locally bounded (Sonn and Storper, 2008) because its transfer requires faceto-face interactions. Finally, Technology Parks aim at providing a supportive environment, enhance entrepreneurs' networks and facilitate access to credit (Storey and Tether, 1998b; Westhead and Batstone, 1998; Heydebreck et al., 2000), alleviating the problems associated especially with new technology based firms (Storey and Tether, 1998a).

In addition to the benefits provided by Technology Parks, Science Park firms gain from the externalities from university research, fostered by the role played by the university within the park.

The importance of universities for firms innovation has been widely acknowledged in scientific literature (Bozeman, 2000, Salter and Martin, 2001; Cohen et al., 2002). More than most economic activities, innovation depends upon new economic knowledge (Audretsch and Feldman, 1996) and universities have traditionally played a major role in originating and promoting the diffusion of knowledge that contribute to industrial innovations (Mansfield and Lee, 1996). In a context of open innovation (Chesbrough, 2003) interorganizational relationships between public research organizations and industry are believed to play an important role in driving innovation processes (Perkmann and Walsh, 2007). Triple Helix paradigm (Etzkowitz and Leydesdorff, 1997) has further emphasised the role played by universities within regional innovation systems.

A large body of literature is concerned with the effects of proximity to a university on firm innovation (for a review, see for example, Lawton Smith, 2007). The main argument is that knowledge spillovers from university research are usually geographically localized, as demonstrated by many empirical studies ${ }^{4}$ (between them Jaffe et al., 1993; Maurseth and Verspagen, 2002; Fischer and Varga, 2003; Sonn and Storper, 2008) mainly due to the localized nature of tacit knowledge transfer (Gertler, 2003). Furthermore, with the greater emphasis put in universities' third mission (Gulbrandsen and Slipersaeter, 2007) technology and knowledge transfer from universities to industry has become a particularly relevant issue (Bozeman, 2000). Universities' third mission is manly fostered through the establishment of links between universities and industry. These links may range from more formal forms of commercialisation of academic knowledge (i.e. patenting, licensing and academic entrepreneurship) to more general academic engagement (Perkmann et al., 2013) including both formal (e.g. collaborative

\footnotetext{
${ }^{4}$ Breschi and Lissoni (2001) criticised the literature on localised pure knowledge spillovers, maintaining that most knowledge spillovers are, de facto, knowledge flows regulated by economic mechanisms.
} 
research, contract research and consulting) and informal activities (e.g. ad hoc advice and networking with practitioners). Academic engagement has been shown to be significantly more valuable for most firms than licensing university patents (Cohen et al., 2002).

Nonetheless, technology and knowledge transfer is not a straightforward process, mainly because university and industry follow very different economic logic, especially when it comes to the appropriability of technology (Foray and Lissoni, 2010) and the management of joint research between university and industry is often challenging (Bercovitz and Feldmann, 2006).

Given this common view on the importance of universities for firms innovation and the obstacles observed, different policies to facilitate academia-industry relations have been adopted (Storey and Tether, 1998b; Bozeman, 2000), being Science Parks one of them. Science Parks aim at institutionalizing certain proximity between their tenant firms and the university (Vedovello, 1997), not only from a geographical perspective. In fact, Science Parks also aim at engendering institutional, organizational, cultural, social and technological proximity, ${ }^{5}$ which are believed to be important for the innovation process (Boschma, 2005). This is relevant, because the distance in these dimensions have been considered as a very important barrier for university-industry transfer (Fransman, 2008; Muscio and Pozzali, 2013).

\subsection{Empirical evidence}

Many empirical studies have dealt with the effect of the on-park location on innovation performance and on the establishment of links between tenant firms and universities.

Regarding innovation performance, Monck et al. (1988), in their pioneering work on STPs, compare 183 on-park with 101 off-park firms in the U.K., finding no significant differences between the two samples in terms of new products launched onto the market and patenting activity. These results are supported by Westhead (1997) in his study on 137 UK firms (75 onand 62 off-park), by Löfsten and Lindelöf (2002) (Sweden, 134 on- and 139 off-park) and by Chan et al. (2011) ${ }^{6}$ (South Africa, 24 on- and 28 off-park). Colombo and Delmastro (2002) (Italy, 45 on- and 45 off-park) observe that on-park location does not affect patenting activity.

On the other hand, some authors find a positive impact of the on-park location on tenants' innovation outputs. In a recent paper, Vasquez-Urriago et al. (2014), using the indicator of sales obtained from new to the market products, report a strong and positive impact of on-park location. They use a very large sample of Spanish firms (39,722 of which 653 on-park) and control for endogeneity bias, which is a common shortcoming of empirical studies on STPs

\footnotetext{
${ }^{5}$ For a review of proximity types see, e.g., Knoben and Oerlemans, 2006.

${ }^{6}$ Chan et al. (2011) find that the on-park location positively affects sales from products new to the firm (but not to the market).
} 
(Phan et al., 2005). Also Siegel et al. (2003b) (UK, 89on- and 88 off-park) find a positive effect, although small in magnitude, of the on-park location on new products sales. Where the patenting activity is concerned, Squicciarini (2008) (Finland, 48 on- and 72 off-park) reports positive impact of the on-park location. In another study (Squicciarini, 2009) she confirms her results performing a duration analysis on a sample of 252 Finnish on-park firms. In the same line, Huang et al. (2012) (Taiwan, 106 firms $^{7}$ ) conclude that locating in STPs positively affects patenting activity of firms. Also Siegel et al. (2003b) observe a positive effect on number of patents, although the magnitude of this effect is quite small when they control for endogeneity bias.

Thus, based on previous empirical evidence, stylized facts on the effect of the on-park location on innovation performance cannot be pointed out.

Regarding the effect on the establishment of links between tenants and universities, a large part of the literature on STPs has emerged. Fostering knowledge and technology transfer between universities and industry is one of the stated objectives of an STP (Storey and Tether, 1998b). With some exceptions, ${ }^{8}$ there is a view that STPs facilitate the establishment of informal links with universities, but more evidence on the establishment of formal links is needed. Felsenstein (1994) (Israel, 66 on- and 96 off-park) reports that low-level interactions (i.e. recruitment of local university graduates, use of university facilities) are more common than high-level interactions (i.e. joint research, industry funding of university research), and that on-park firms are more likely to report the former type of interactions. These results are confirmed by Westhead and Storey (1995) (UK, 75 on- and 62 off-park), Vedovello (1997) (UK, 21 on-park) and Löfsten and Lindelöf (2002) who find that STPs facilitate the establishment of informal links, but that there is mostly no influence on establishment of high-level (more formal) links with universities or other higher education institutions. On the other hand, some authors demonstrate that the on-park location has a positive effect also on the establishment of formal links. Colombo and Delmastro (2002) and Fukugawa (2006) (Japan, 72 on- and 66 off-park) conclude that on-park firms are more likely also to engage in formal agreements, such as joint research with universities than firms in an off-park sample. Recently, a paper by VásquezUrriago et al. (2016b, Spain, 39,722 firms, 653 on-park) concludes that on-park location has a strong and positive effect on firms' propensity to cooperate ${ }^{9}$ on innovation activities. Caldera

\footnotetext{
${ }^{7}$ Huang et al. (2012) sample is composed by 28 on-park firms, 27 firms located in an industrial park and 51 in a spontaneous cluster.

${ }^{8}$ The findings in Monck et al. (1988) from a study of STPs in UK are very similar for propensity for establishing links with local universities between on- and off-park firms. These results are confirmed by Quintas et al. (1992) and Malairaja and Zawdie (2008), who find no statistically significant differences between the on- and off-park samples.

${ }^{9}$ Not exclusively with a university.
} 
and Debande (2010) show that the ownership of an STP by a university helps university in increasing R\&D income, which, more likely, comes from on-park firms.

As stated in the introduction section of this paper, previous research has mainly been focused on assessing the homogeneous effect of the on-park location, typically comparing the outcomes of on-park and off-park firms. Tenants and parks heterogeneity has been almost disregarded so far and, in particular, the fact that some parks are Science Parks, with a strong university presence, while other are Technology Parks, with no formal link with a university, has not been taken into account so far. We believe this is an important source of park heterogeneity, that may affect tenants' innovation output and collaboration patterns with universities.

\subsection{Science and Technology Parks and expected results}

The importance of considering university involvement as a source of parks heterogeneity has, thus, many theoretical justifications. Nonetheless making clear starting hypothesis on the effect of the involvement of universities in STPs on tenants' innovation outputs and on their links with universities, is not straightforward.

First, regarding innovation sales, as we saw, there is a large body of literature pointing out the benefits for firm innovation output deriving from collaboration with universities and from university knowledge spillovers. On the other hand, universities, especially in Spain, have traditionally suffered problems in transforming their notable scientific production in innovative output (Albert and Plaza, 2004). To what extent this lack of competences in commercial skills is counterbalanced by Science Parks is an interesting issue, to which we are attempting to contribute in this paper.

Second, regarding the number of patents, on the one hand patents can be considered as a intermediate output which constitute an input for future developments. We may expect that the type of knowledge in parks with a stronger university presence is more science-oriented, thus more suitable for being protected through patents (Czarnitzki et al, 2009). Furthermore collaborative projects, like those between universities and firms, tend to increase patenting activity (Czarnitzki et al., 2007). On the other hand, collaboration between actors characterised by profoundly different economic logic such as industry and university (Forey and Lissoni, 2010) may lead to unsolved issues regarding IP that, in some cases, represent 'an insurmountable barrier which prevents the sought-after research partnership from ever coming about' (Hall et al., 2001). This would affect both innovation output and collaboration patterns.

Finally, also for the effect of university involvement on tenants cooperation with universities there are contrasting theoretical argument. On the one hand, enhance relations university- 
industry has been found to be one of the main reasons for universities involvement in STPs (Storey and Tether, 1998b). Some studies have shown that firms locate on-park also to get access to university's facilities and more in general for the prestige to be linked to a university (Westhead and Batstone, 1998; Phillips and Yeung, 2003). On the other hand, some are critical of the role played by Science Parks in enhancing university-industry relations. In particular, Hansson et al. (2005) claim that the model of parks as intermediaries between university and industry has the opposite effect, that is institutionalizing certain distance instead of proximity, and results in low levels of interaction. Furthermore, the park's role as a bridging institution may not be legitimated since the interests of the Science Park's management, those of the university and those of park's firms may be different ${ }^{10}$ (Foray and Lissoni, 2010).

\section{Science and Technology Parks in Spain}

STPs importance in Spanish innovation and technology policy scenario is widely recognised (Vásquez-Urriago et al., 2014, Albahari et al., 2013). Since the first STP appears in 1985 (Parque Tecnológico de Bizkaia, Bizkaia), the number of STPs has grown at a very high pace, reaching the considerable number of 47 operative STPs at the end of 2014, hosting approximately 6,500 firms and employing more than 150,000 workers (Fig.1), 31,000 of which dealing with R\&D activities ${ }^{11}$ (APTE, 2015). This rapid development of STPs movement in Spain has been nurtured by the strong interest of the central and local governments in STPs as an instrument of technology and innovation policy. The considerable public funds invested in parks' creation and growth (Albahari, 2013; COTEC, 2011) led some authors to claim that STPs have been one of the most important innovation policies in Spain (Vásquez-Urriago et al., 2014).

The fact that the headquarter of the International Association of Science Parks and Areas of Innovation $^{12}$ (IASP) is located in Spain is a further signal of the weight of the Spanish STPs movement.

Unlike what happened in other countries, e.g. in the UK (Siegel et al., 2003a), in the Spanish experience, universities have initially played a marginal role in STPs creation, which was due almost exclusively to the political initiative. The first university-driven STP, the Parc Cientific

\footnotetext{
${ }^{10}$ E.g. to maximize their income, STPs are keen to rent all available spaces, which can result in less rigid admission criteria.

${ }^{11}$ These figures refer to APTE (the Spanish Association of Science and Technology Parks) members only. To our knowledge, the only sizeable (in terms of numbers of employees and tenants) park that is not a member of APTE is the Parque de la Innovación de Navarra.

${ }^{12}$ IASP is the worldwide network of Science Parks and areas of innovation. Created in 1984, it has currently 375 members in 70 countries.
} 
de Barcelona, constituted in 1997, started a second wave of STPs in which universities assumed a more central role. Given the idiosyncratic development of the STPs movement in Spain, characterized by a high heterogeneity of parks' founders, promoters and stakeholders (see Table 1), in particular with respect to the level of involvement of universities within parks, we believe that Spain is the ideal place to conduct this research.

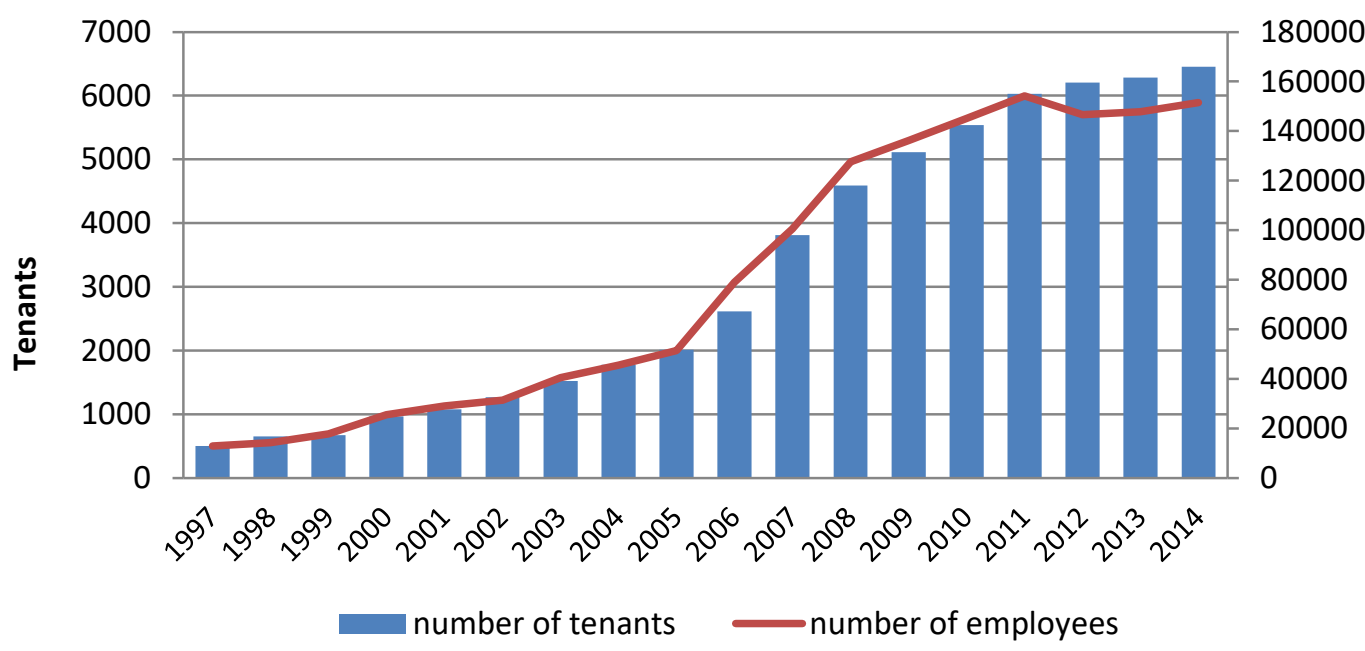

Figure 1. Evolution of the number of tenants and employees in APTE's parks (Adapted from APTE, 2015)

Table 1. Parks included in the sample ${ }^{13}$ with social capital share per shareholders' type.

\begin{tabular}{l|l|l|l|l}
\hline \hline Park's name & $\begin{array}{l}\text { Year of } \\
\text { foundation }\end{array}$ & Province, Region & $\begin{array}{l}\text { Number of } \\
\text { tenants }\end{array}$ & $\begin{array}{l}\text { Shareholder' } \\
\text { s type }^{(a)}\end{array}$ \\
\hline \hline Parque Tecnológico de Bizkaia & 1985 & $\begin{array}{l}\text { Biscay, Basque } \\
\text { Country }\end{array}$ & 227 & G, U \\
\hline Parc Tecnológic del Vallés & 1987 & Barcelona, Catalonia & 149 & G \\
\hline Valéncia Parc Tecnológic & 1990 & $\begin{array}{l}\text { Valencia, Valencian } \\
\text { Community }\end{array}$ & 421 & G \\
\hline Parque Científico y Tecnológico & 1991 & Seville, Andalusia & 345 & G, U, F \\
Cartuja 93 & 1991 & Asturias, Asturias & 113 & G \\
\hline Parque Tecnológico de Asturias & 1991 & Ourense, Galicia & 89 & G, U, F, P \\
\hline Parque Tecnolóxico de Galicia & 1992 & $\begin{array}{l}\text { Alava, Basque } \\
\text { Country }\end{array}$ & 106 & G \\
\hline Parque Tecnológico de Álava & & & &
\end{tabular}

${ }^{13}$ In the study were included only fully operative parks with, at least, two years of full-membership in APTE. 


\begin{tabular}{|c|c|c|c|c|}
\hline Parque Tecnológico de Andalucía & 1992 & Malaga, Andalusia & 526 & $\mathrm{G}, \mathrm{F}$ \\
\hline $\begin{array}{l}\text { Parques Tecnológicos de Castilla y } \\
\text { León }\end{array}$ & 1992 & $\begin{array}{l}\text { Valladolid, León and } \\
\text { Burgos; Castile and } \\
\text { Leon }\end{array}$ & 162 & G, F \\
\hline Parque Tecnológico de San Sebastián & 1994 & $\begin{array}{l}\text { Gipuzkoa, Basque } \\
\text { Country }\end{array}$ & 70 & $\mathrm{G}$ \\
\hline Parc Científic de Barcelona & 1997 & Barcelona, Catalonia & 93 & $\mathrm{U}, \mathrm{F}$ \\
\hline $\begin{array}{l}\text { Parque Balear de Innovación } \\
\text { Tecnológica (ParcBIT) }\end{array}$ & 1997 & $\begin{array}{l}\text { Balearic Islands, } \\
\text { Balearic Islands }\end{array}$ & 103 & $\mathrm{G}$ \\
\hline $\begin{array}{l}\text { Parque Tecnológico de Ciencia de la } \\
\text { Salud de Granada }\end{array}$ & 1997 & Granada, Andalusia & 75 & $\mathrm{G}, \mathrm{U}, \mathrm{F}, \mathrm{P}$ \\
\hline Parque Científico de Alicante & 1998 & $\begin{array}{l}\text { Alicante, Valencian } \\
\text { Community }\end{array}$ & 9 & $\mathrm{U}$ \\
\hline $\begin{array}{l}\text { Centro de Desarrollo Tecnológico de } 1 \\
\text { a Universidad de Cantabria (CDTUC) }\end{array}$ & 1999 & Cantabria, Cantabria & 20 & G, $P$ \\
\hline 22@Barcelona & 2000 & Barcelona, Catalonia & 1437 & $\mathrm{G}$ \\
\hline $\begin{array}{l}\text { Parque Científico - Tecnológico de } \\
\text { Gijón }\end{array}$ & 2000 & Asturias, Asturias & 54 & G \\
\hline $\begin{array}{l}\text { Parque Científico de Leganés } \\
\text { Tecnológico }\end{array}$ & 2000 & $\begin{array}{l}\text { Madrid, Community } \\
\text { of Madrid }\end{array}$ & 71 & $\mathrm{G}$ \\
\hline Fundació Parc d'Innovació La Salle & 2001 & Barcelona, Catalonia & 16 & $\mathrm{U}$ \\
\hline Parque Científico de Madrid & 2001 & $\begin{array}{l}\text { Madrid, Community } \\
\text { of Madrid }\end{array}$ & 114 & $\mathrm{U}$ \\
\hline $\begin{array}{l}\text { Parque Científico y Tecnológico de Al } \\
\text { bacete }\end{array}$ & 2001 & $\begin{array}{l}\text { Albacete, Castile-La } \\
\text { Mancha }\end{array}$ & 30 & $\mathrm{G}, \mathrm{U}$ \\
\hline $\begin{array}{l}\text { Parque Tecnológico y Logístico de } \\
\text { Vigo }\end{array}$ & 2001 & Pontevedra, Galicia & 84 & $\mathrm{G}$ \\
\hline Ciudad Politécnica de la Innovación & 2002 & $\begin{array}{l}\text { Valencia, Valencian } \\
\text { Community }\end{array}$ & 52 & $\mathrm{U}$ \\
\hline Parque Tecnológico Walqa & 2002 & Huesca, Aragon & 62 & $\mathrm{G}, \mathrm{F}$ \\
\hline $\begin{array}{l}\text { TecnoAlcalá. Parque Científico - Tecn } \\
\text { ológico de la Universidad de Alcalá }\end{array}$ & 2003 & $\begin{array}{l}\text { Madrid, Community } \\
\text { of Madrid }\end{array}$ & 37 & $\mathrm{G}$ \\
\hline
\end{tabular}

${ }^{\text {(a) }}$ G: governmental bodies, U: universities; F: private financial sector; P: private non-financial sector 


\section{Empirical framework}

\subsection{Empirical model}

We want to estimate the effect of type of STP (based on the degree of involvement of universities in an STP) on firms' innovation results and links with universities. The empirical model can be written as:

$$
Y=\alpha+\beta \text { STP }_{\text {type }}+\gamma \text { FirmControls }+\lambda \text { STPControls }+u
$$

where $Y$ is the dependent variable and STPtype is a vector of dummy variables for different STP types, according to the degree of involvement of the university. Since the objective is to analyse the effect of different STP types on firms' innovation results and firms' links with universities, it is crucial to account for potential confounding factors. On the one hand, we expect that firm characteristics differ across STP types (e.g., firms in Science Parks are likely to be more science oriented than those in Technology Parks). Thus, we need to adequately control for firm characteristics in order to obtain unbiased estimates of $\beta$. On the other hand, we expect that also STP characteristics will differ across STP types (e.g. Science Parks may be smaller). Thus, we also need to control for STP characteristics to obtain unbiased estimates of $\beta$.

Our main analysis uses a hierarchical regression approach, starting by the simplest model without controls. In a second step, we include firm characteristics, while in a third step we also account for STP characteristics. Finally, we explore if the provision of services and the staff employed by different types of parks may be considered as potential channels through which the influence takes place.

Although we include a wide set of firm covariates in this analysis, the firm's specific innovation orientation (more or less scientific) is not included in the main analysis because we do not have a proxy for this variable available for the whole sample. However, we have a reasonable proxy at our disposal for a large subsample of firms (those with an internal R\&D department): the percentage of $\mathrm{PhDs}$ in the $\mathrm{R} \& \mathrm{D}$ staff, which proxies for the degree of scientific orientation of the firm. Accordingly, we perform an additional check for omitted variable bias using this proxy. $^{14}$

We present results from OLS estimations. As Angrist and Pischke (2008) show, OLS is the minimum mean squared error linear approximation to the underlying conditional expectation function of the dependent variable. We can think about OLS as a 'scheme to compute marginal effects'. This scheme shows several virtues: simplicity, automation and comparability across

\footnotetext{
${ }^{14}$ For a detailed analysis on the role played by PhDs in Spanish firms, see for example, Herrera and Nieto (2015).
} 
studies. In addition, they do not require any distributional assumption. As we are interested in marginal effects we decided to present OLS $^{15}$.

\subsection{Data}

We combine data from two different sources: firm-level data from the 2009 Spanish CIS with park-level data from the Survey 2009 on the Characteristics and Results of Science and Technology Parks. ${ }^{16}$ The 2009 CIS for Spain (available since 2011) is managed by the Spanish National Statistics Institute (INE). The CIS collects very detailed information on the characteristics of firms' innovation processes and, since 2007 has included a question about possible on-park location. The 2009 CIS covered 37,201 firms representative of the Spanish business structures, 849 of which were on-park firms involving $25 \mathrm{STPs}^{17}$ in 12 different Spanish regions. The survey data allow use of a wide set of covariates and enable higher levels of heterogeneity across STPs than previous studies. Since the Spanish CIS is modelled on the European CIS, it allows comparisons to be made with other studies using $\mathrm{CIS}^{18}$. Other secondary data sources are INE national accounting and INE population census data.

\subsection{Variables definition}

\subsubsection{Independent variables}

Our main objective is to show the influence of the degree of involvement of universities in the STP on tenant firms' innovation performance and links with universities. As already mentioned, the variety of STP experience in relation to the degree of involvement of universities within parks makes Spain a good case study. We distinguish four types of STPs, ranging from parks wholly or partly owned and managed by a university, which we describe as Pure Science Parks to parks with no formal links to a university, which we describe as Pure Technology Parks. Between these extremes are STPs where a university is a minority shareholder, described as Mixed Parks and parks where a university (although not a shareholder) has some research facilities located in the STP, which we describe as Technology Parks with University.

\footnotetext{
${ }^{15}$ Marginal effects from OLS are very similar from marginal effect from non linear models computed at the mean of covariates.

${ }^{16}$ Although central government is not directly involved in any STP initiatives, response to this survey is required in order for STPs to access government funding (Albahari et al., 2013). In a few cases, missing data for a particular park required direct contact with the relevant park manager.

${ }^{17}$ Our STP sample includes only those STPs that were full members of the Association of Science and Technology Parks of Spain (APTE) for at least two years before 2009.

${ }^{18}$ To carry out this research, we were granted access to data in secured places in INE. Unfortunately, we cannot use panel data because we can only observe the specific park in which the firm is located for 2009. Although a panel database (PITEC) based on Spanish CIS data is available online, it does not specify to which park tenants belong.
} 
Using data on each park shareholder, and information on the presence of university facilities in the STP, we define four dummies variables, according to the degree of involvement of the university. Pure_Science_Park takes the value 1 if the park is a Pure Science Park, that is with more than 50\% university ownership, and 0 otherwise. Mixed_Park takes the value 1 if the park is a Mixed Park, that is, there is a minority (less than 50\%) university shareholding, and 0 otherwise; Tech_Park_with_University takes the value 1 if the park is a Technology Park hosting some university research facilities, and 0 otherwise; Pure_Technology_Park takes the value 1 if the park is a Pure Technology Park, that is no university presence. ${ }^{19}$

In our sample, five parks are Pure Science Parks, five are Mixed Parks, eight are Technology Parks with a University and seven are Pure Technology Parks. The number of firms per park type is respectively, 112, 206, 260 and 271 (see Table 2).

Table 2. Park types' definition and number of parks and firms in the sample.

\begin{tabular}{|c|c|c|c|c|}
\hline & Park type & Characteristics & \# of parks & $\begin{array}{l}\text { \# of firms in } \\
\text { the sample }\end{array}$ \\
\hline \multirow{2}{*}{ 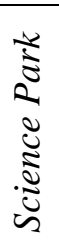 } & Pure Science Park & $\begin{array}{l}\text { STP with more than the } \\
50 \% \text { of shares owned by } \\
\text { the university }\end{array}$ & 5 & 112 \\
\hline & Mixed Park & $\begin{array}{l}\text { STP where the university } \\
\text { is a minority shareholder }\end{array}$ & 5 & 206 \\
\hline \multirow{2}{*}{ 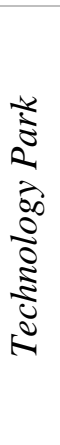 } & $\begin{array}{l}\text { Technology Park with } \\
\text { University }\end{array}$ & $\begin{array}{l}\text { STP where the university } \\
\text { is not a shareholder, but it } \\
\text { locates some of its } \\
\text { research facilities inside } \\
\text { the STP }\end{array}$ & 8 & 260 \\
\hline & Pure Technology Park & $\begin{array}{l}\text { STP where the university } \\
\text { is not a shareholder nor } \\
\text { locates some of its } \\
\text { research facilities inside } \\
\text { the STP }\end{array}$ & 7 & 271 \\
\hline
\end{tabular}

\subsubsection{Dependent variables}

Our dependent variables aim at measuring the innovation performance of tenant firms and their relations with universities.

\footnotetext{
${ }^{19}$ Managers of Pure Technology Parks were contacted by phone or email, to confirm that the university has not located any research facility inside the park.
} 


\section{Innovation performance}

The first indicator of on-park firms' innovation performance that we use is sales from new to the market products, lnew_prod. We have data for each firm in the CIS survey. This indicator is used in several studies of innovation (for a review see e.g. Barge-Gil, 2013). It is argued that it overcomes problems associated with other indicators such as patents, R\&D expenses and number of innovations (Griliches, 1998). Operationally, the dependent variable lnew_prod is the logarithm of the sales obtained from new to the market products per employee, for products introduced in the period 2007-2009.

Another indicator for firm innovation output used in our models is lpatents. This variable is the logarithm of number of patent applications ${ }^{20}$ per employee. Number of patents is a widely used indicator of innovation performance in previous work (Griliches, 1998) and there is a body of evidence on the effect of on-park location on the patenting activity of firms (see section 2.1).

\section{Links between tenants and universities}

We proxy the link between a university and an on-park firm using two indicators: coop_uni is a dummy variable that takes the value 1 if the firm cooperates ${ }^{21}$ with a university; $R \& D$ is the amount of external $R \& D$ bought from a university, defined operationally as the logarithm of total expenditure on $R \& D$ services sourced from a university per employee. In our intentions, while $R \& D$ is an indicator of formal collaboration, coop_uni also capture less formal collaboration between universities and firms, which has been found to be practised by a far larger proportion of academics than commercialisation (i.e. patenting and licensing) (Perkmann et al., 2013). Both formal and informal links have been shown to be relevant for innovation results (García-Pérez-de-Lema et al., 2016).

\subsubsection{Control variables - firm level}

Previous studies using CIS data show the importance of general firm characteristics (i.e. total turnover, exports, industry sector, firm age) and innovation-specific characteristics (i.e. innovation effort, percentage of employees with a $\mathrm{PhD}$, perceived obstacles to innovation) as determinants of innovation outputs (for a review see Vásquez-Urriago et al., 2014) and links

\footnotetext{
${ }^{20}$ It refers to the total number of patent applications. If the same file is sent to different IP offices (e.g. EPO, USPTO, OEPM, etc.) it is counted only once.

${ }^{21}$ The CIS refers to cooperation as active participation with other organizations on innovation activities; this does not include subcontracting.
} 
with universities (for a review see Veugelers and Cassiman, 2005). The list of covariates used in the present study is shown in Table 3.

Table 4 shows that firm characteristics seem to be related also to park type. Firms in Pure Science Park and Mixed Park are younger, smaller and more R\&D intensive. The more scientifically oriented the park, the higher the percentage of knowledge intensive firms. We need to control for these covariates such that estimates of $\beta$ capture the effects of different types of STPs, and do not confound them with the effect of firms' characteristics differing across park types. 
Table 3. Firms' Covariates.

\begin{tabular}{|c|c|c|}
\hline Characteristic & Label & Description \\
\hline Turnover & $\begin{array}{l}\text { lfirm_sales } \\
\text { lfirm_sales_q }\end{array}$ & $\begin{array}{l}\text { Turnover in } 2007 \text { (log) } \\
\text { Turnover in } 2007 \text { (log, quadratic) }\end{array}$ \\
\hline Exports & firm_exports & Exports over turnover in 2007 \\
\hline Industrial sector & $\begin{array}{l}\text { firm_industry_ } \\
\text { high } \\
\text { firm_industry_ } \\
\text { mhigh } \\
\text { firm_industry_ } \\
\text { mlow } \\
\text { firm_industry_ } \\
\text { low } \\
\text { firm_industry_ } \\
\text { firm_industry_ } \\
\text { kis } \\
\text { firm_industry_ } \\
\text { nkis } \\
\text { firm_industry_ } \\
\text { restact }\end{array}$ & $\begin{array}{l}\text { Technological level of industrial sector }(0,1) \\
\text { (according to OECD Science, Technology and } \\
\text { Industry Scoreboard) } \\
7 \text { dummies: high-tech manufacturing, medium- } \\
\text { high-tech manufacturing, medium-low-tech } \\
\text { manufacturing, low-tech manufacturing, knowledge } \\
\text { intensity service, no-knowledge intensity service, } \\
\text { other sectors }\end{array}$ \\
\hline Age & lfirm_age & Firm age (years) $(\log )$ \\
\hline Innovation effort & $\begin{array}{l}\text { firm_innov_ef } \\
\text { fort }\end{array}$ & $\begin{array}{l}\text { Expenditure on innovation activities in } 2007 \text { per } \\
\text { employee (thousand euros) }\end{array}$ \\
\hline Location & lgdp_prov & Provincial GDP per capita $(\log )$ \\
\hline $\begin{array}{l}\text { Cost obstacles to } \\
\text { innovation }\end{array}$ & firm_costobst & $\begin{array}{l}\text { Perceived average importance of the following } \\
\text { factors as a barrier to innovation during 2007-2009: } \\
\text { - lack of internal funds } \\
\text { - lack external funds } \\
\text { - high costs of innovating } \\
\text { - risk costs due to uncertain demand of innovative } \\
\text { products and services } \\
\text { (scale: } 1 \text { - } 4 ; 1 \text { very important; } 4 \text { unimportant) }\end{array}$ \\
\hline $\begin{array}{l}\text { Information obstacles to } \\
\text { innovation }\end{array}$ & firm_infobst & $\begin{array}{l}\text { Perceived average importance of the following } \\
\text { factors as barriers to innovation during 2007-2009: } \\
\text { - lack of qualified personnel } \\
\text { - lack of information on technology } \\
\text { - lack of information on the markets } \\
\text { - difficulty to find cooperation partners } \\
\text { (scale: } 1 \text { - 4; } 1 \text { very important; } 4 \text { unimportant) }\end{array}$ \\
\hline
\end{tabular}


Table 4. Control variables - firm level per type of park. Means.

\begin{tabular}{lcccc}
\hline & $\begin{array}{c}\text { Pure Science } \\
\text { Parks } \\
(112 \text { obs.) }\end{array}$ & $\begin{array}{c}\text { Mixed Parks } \\
(206 \text { obs. })\end{array}$ & $\begin{array}{c}\text { Technology } \\
\text { Parks with } \\
\text { University } \\
\text { (260 obs. })\end{array}$ & $\begin{array}{c}\text { Pure } \\
\text { Technology } \\
\text { Parks } \\
(271 \text { obs. })\end{array}$ \\
\hline firm_age & 9.11 & 11.45 & 13.06 & 14.59 \\
firm_sales & $2.03 \mathrm{e}+07$ & $0.99 \mathrm{e}+07$ & $1.24 \mathrm{e}+07$ & $1.81 \mathrm{e}+07$ \\
firm_exports & 0.02 & 0.03 & 0.04 & 0.04 \\
firm_innov_effort & 52069.72 & 42728.68 & 27853.12 & 22280.33 \\
gdp_prov $\left.{ }^{*}\right)$ & 28.21 & 23.28 & 24.96 & 24.38 \\
firm_industry_low & 0.04 & 0.02 & 0.03 & 0.06 \\
firm_industry_mlow & 0.00 & 0.02 & 0.04 & 0.05 \\
firm_industry_mhigh & 0.03 & 0.07 & 0.06 & 0.12 \\
firm_industry_high & 0.08 & 0.07 & 0.10 & 0.07 \\
firm_industry_kis & 0.76 & 0.67 & 0.66 & 0.55 \\
firm_industry_nkis & 0.07 & 0.10 & 0.07 & 0.10 \\
firm_industry_restact & 0.02 & 0.05 & 0.04 & 0.05 \\
firm_costobst & 0.57 & 0.54 & 0.55 & 0.55 \\
firm_infobst & 0.39 & 0.39 & 0.40 & 0.39 \\
\hline (*) & & & &
\end{tabular}

${ }^{(*)}$ thousands of Euros.

\subsubsection{Control variables - park level}

Albahari et al. (2016) show that the characteristics of the STP significantly affect tenants' innovation results. We distinguish between two types of STP characteristics: structural characteristics (age and size), and managerial characteristics (size of the management entity, and provision of services) (Table 5). Table 6 shows that park characteristics are related also to park type. Spanish Pure Science Parks are the youngest and smallest type of park; they have larger management teams and provide more services. We include park's structural characteristics as control variables to avoid biases in the estimations of $\beta$. Regarding managerial characteristics they could be regarded as channels of influence of the different park types so that we will include them only for exploratory purposes. 
Table 5. Control variables - Park level.

\begin{tabular}{|c|c|c|c|}
\hline & Characteristic & Label & Description \\
\hline \multirow{3}{*}{ 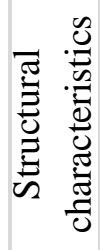 } & \multirow{2}{*}{ Age } & park_age & Age of the STP (years) \\
\hline & & park_agesq & Age of the STP (quadratic) \\
\hline & Dimension & lpark_firms & Number of tenant organizations in $2008(\log )$ \\
\hline \multirow{3}{*}{ 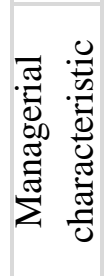 } & \multirow{3}{*}{ Management } & lpark_staff & $\begin{array}{l}\text { Number of full-time equivalent employees in the } \\
\text { park's management company per } 100 \text { tenants (log) }\end{array}$ \\
\hline & & park_services_i & $\begin{array}{l}1 \text { if the park provides services to foster } \\
\text { internationalization of firm, } 0 \text { otherwise }\end{array}$ \\
\hline & & park_services_c & $\begin{array}{l}1 \text { if the park provides advice on legal, commercial } \\
\text { and fiscal issues, } 0 \text { otherwise }\end{array}$ \\
\hline
\end{tabular}

STP age (park_age, number of years since park establishment) is included in its quadratic form $\left(\right.$ park_agesq $\left.{ }^{22}\right)$.

lparkfirms is the log of number of park tenants at the end of the year previous to the survey (2008), and proxies for park size.

The independent variables related to the characteristics of park management are: a) lpark_staff, number of full-time equivalent employees in the park's management company per 100 tenants $(\log )$; b) park_services_ $i$, a dummy variable that takes the value 1 if the park management provides services to foster internationalization of its tenants, and 0 otherwise; c) park_services_c, a dummy variable that takes the value 1 if the park management provides legal, commercial and/or fiscal consulting services to its tenants, and 0 otherwise.

Table 6. Control variables - park level per type of park. Means.

\begin{tabular}{lcccc}
\hline & $\begin{array}{c}\text { Pure Science } \\
\text { Parks }\end{array}$ & $\begin{array}{c}\text { Mixed } \\
\text { Parks }\end{array}$ & $\begin{array}{c}\text { Technology } \\
\text { Parks with } \\
\text { University }\end{array}$ & $\begin{array}{c}\text { Pure } \\
\text { Technology } \\
\text { Parks }\end{array}$ \\
\hline park_age & 8.97 & 19.42 & 15.91 & 15.11 \\
park_firms & 150.29 & 206.55 & 290.42 & 205.26 \\
park_staff & 93.11 & 14.99 & 14.40 & 23.23 \\
park_services_i & 0.87 & 0.89 & 0.42 & 0.56 \\
park_services_c & 0.87 & 0.18 & 0.08 & 0.26 \\
\hline
\end{tabular}

\footnotetext{
${ }^{22}$ According to Albahari et al. (2016) age of Spanish STPs shows an U-shaped relationship with tenants' performance.
} 
Table 7 presents descriptive statistics for the variables used in our models for the 849 sample firms. Descriptive statistics for the same variables per park type are presented in the Annex (tables A1 to A4).

Table 7. Descriptive statistics (849 observations).

\begin{tabular}{|c|c|c|c|c|}
\hline & Mean & Std. Dev. & Min. & Max. \\
\hline \multicolumn{5}{|l|}{ Dependent Variables } \\
\hline new_prod & 14387.06 & 43567.13 & 0 & 607684.40 \\
\hline patents & 520.12 & 1920.81 & 0 & 26000 \\
\hline coop_uni & 0.34 & 0.47 & 0 & 1 \\
\hline RDboughtl & 755.11 & 2782.42 & 0 & 34352.50 \\
\hline \multicolumn{5}{|c|}{ Independent variables - STPs' characteristics } \\
\hline park_age & 15.59 & 5.12 & 6 & 24 \\
\hline park_firms & 224.40 & 218.10 & 2 & 1436 \\
\hline park_staff & 27.75 & 68.32 & 0 & 1550 \\
\hline park_services_i & 0.64 & 0.48 & 0 & 1 \\
\hline park_services_c & 0.26 & 0.44 & 0 & 1 \\
\hline \multicolumn{5}{|c|}{ Control variables - firms' characteristics } \\
\hline firm_age & 12.64 & 12.00 & 1 & 152 \\
\hline firm_sales & $1.46 \mathrm{e}+07$ & $6.98 \mathrm{e}+07$ & 0 & $1.02 \mathrm{e}+09$ \\
\hline firm_exports & 0.03 & 0.12 & 0 & 0.95 \\
\hline firm_innov_effort & 32878.32 & 68140.92 & 0 & 915000 \\
\hline gdp_prov ${ }^{(*)}$ & 24.79 & 5.33 & 17.08 & 34.49 \\
\hline firm_industry_low & 0.04 & 0.19 & 0 & 1 \\
\hline firm_industry_mlow & 0.03 & 0.18 & 0 & 1 \\
\hline firm_industry_mhigh & 0.08 & 0.27 & 0 & 1 \\
\hline firm_industry_high & 0.07 & 0.26 & 0 & 1 \\
\hline firm_industry_kis & 0.64 & 0.48 & 0 & 1 \\
\hline firm_industry_nkis & 0.09 & 0.28 & 0 & 1 \\
\hline firm_industry_restact & 0.04 & 0.20 & 0 & 1 \\
\hline firm_costobst & 0.55 & 0.20 & 0.25 & 1 \\
\hline firm_infobst & 0.39 & 0.13 & 0.25 & 1 \\
\hline
\end{tabular}

${ }^{(*)}$ thousands.

\section{Results}

\subsection{Influence of park types on innovation outputs}

\subsubsection{Main analysis}

We estimate equation (1) using OLS regressions, adopting a hierarchical approach and clustering standard errors by park. The effect of park type on innovation is shown in Table 8. Column I provides a crude view of the effect of park type on sales of new products per employee; it shows no differences because park types are related to different firm and park characteristics. Column II includes the set of firm covariates, but does not control for park characteristics; there are no significant differences across park types. Column III includes measures for parks' 'structural' characteristics (age and size). These characteristics have been 
shown to be relevant for explaining the performance of tenant firms (Albahari et al., 2016) and, as previously shown, are correlated with park type (see Table 6). They should be included in the regressions to avoid omitted variables bias. When the effect of these variables is controlled for, we observe that firms located in Pure Science Parks and in Mixed Parks show lower levels of sales from new products than firms in other types of parks with no university presence. These results highlight the importance of controlling for firm and park characteristics to adequately estimate the effect of park type.

Finally, we also include managerial characteristics (management team size, and provision of internationalization and consultancy services). The reason not to include them in the previous regression is that they can be a channel through which the influence of universities takes place (for example, it could well be that parks with a high degree of involvement of a university show better provision of services to tenants). Results hold when the variables capturing park management are included (Column IV). The magnitude of the effects is quite large, $122 \mathrm{log}$ points for Pure Science Parks, and 96 log points for Mixed Parks (roughly $70 \%$ and $62 \%$ fewer sales of new products per employee, respectively).

Among firm covariates, it is remarkable that their results are very robust to the inclusion of STP characteristics and are in line with studies showing the importance of innovation efforts (Czarnitzki and Hottenrott, 2009; Frenz and Ietto-Gillies, 2009; Tsai, 2009) and firm age (Czarnitzki and Hottenrott, 2009) for explaining sales of new to the market products, and the insignificant influence of industry when other factors are accounted for (Frenz and Ietto-Gillies, 2009; Faems et al., 2005). In addition, we find no significant effect for size, exports or obstacles to innovation. 
Table 8. Influence of park type on innovation outputs. Main specification.

\begin{tabular}{|c|c|c|c|c|c|c|c|c|}
\hline & $\begin{array}{c}\text { (I) } \\
\text { lnew_prod }\end{array}$ & $\begin{array}{c}\text { (II) } \\
\text { lnew_prod }\end{array}$ & $\begin{array}{c}\text { (III) } \\
\text { lnew_prod }\end{array}$ & $\begin{array}{c}\text { (IV) } \\
\text { lnew_prod }\end{array}$ & $\begin{array}{c}(\mathrm{V}) \\
\text { lpatents }\end{array}$ & $\begin{array}{c}\text { (VI) } \\
\text { lpatents }\end{array}$ & $\begin{array}{c}\text { (VII) } \\
\text { lpatents }\end{array}$ & $\begin{array}{l}\text { (VIII) } \\
\text { lpatents }\end{array}$ \\
\hline $\begin{array}{l}\text { Pure_Science_ } \\
\text { Park }\end{array}$ & $\begin{array}{l}-0.116 \\
(0.408)\end{array}$ & $\begin{array}{l}-0.526 \\
(0.432)\end{array}$ & $\begin{array}{l}-0.772^{*} \\
(0.359)\end{array}$ & $\begin{array}{l}-1.223^{* *} \\
(0.385)\end{array}$ & $\begin{array}{l}1.873^{\text {**** }} \\
(0.340)\end{array}$ & $\begin{array}{l}1.352^{* * *} \\
(0.328)\end{array}$ & $\begin{array}{l}1.434^{* *} \\
(0.383)\end{array}$ & $\begin{array}{l}1.399^{* * *} \\
(0.409)\end{array}$ \\
\hline Mixed_Park & $\begin{array}{l}-0.275 \\
(0.601)\end{array}$ & $\begin{array}{l}-0.512 \\
(0.497)\end{array}$ & $\begin{array}{l}-1.009^{* *} \\
(0.353)\end{array}$ & $\begin{array}{l}-0.957^{* * *} \\
(0.286)\end{array}$ & $\begin{array}{c}0.283 \\
(0.264)\end{array}$ & $\begin{array}{c}0.073 \\
(0.274)\end{array}$ & $\begin{array}{l}-0.055 \\
(0.304)\end{array}$ & $\begin{array}{c}0.115 \\
(0.331)\end{array}$ \\
\hline $\begin{array}{l}\text { Tech_Park_wi } \\
\text { th_University }\end{array}$ & $\begin{array}{l}-0.233 \\
(0.441)\end{array}$ & $\begin{array}{l}-0.559 \\
(0.387)\end{array}$ & $\begin{array}{l}-0.531 \\
(0.318)\end{array}$ & $\begin{array}{l}-0.328 \\
(0.252)\end{array}$ & $\begin{array}{c}0.240 \\
(0.353)\end{array}$ & $\begin{array}{c}0.014 \\
(0.336)\end{array}$ & $\begin{array}{c}0.001 \\
(0.316)\end{array}$ & $\begin{array}{l}-0.034 \\
(0.307)\end{array}$ \\
\hline lfirm_sales & & $\begin{array}{c}0.118 \\
(0.101)\end{array}$ & $\begin{array}{c}0.131 \\
(0.099)\end{array}$ & $\begin{array}{c}0.127 \\
(0.100)\end{array}$ & & $\begin{array}{c}0.010 \\
(0.059)\end{array}$ & $\begin{array}{c}0.012 \\
(0.059)\end{array}$ & $\begin{array}{c}0.010 \\
(0.058)\end{array}$ \\
\hline 1firm_sales_q & & $\begin{array}{l}-0.005 \\
(0.007)\end{array}$ & $\begin{array}{l}-0.006 \\
(0.007)\end{array}$ & $\begin{array}{l}-0.006 \\
(0.007)\end{array}$ & & $\begin{array}{l}-0.004 \\
(0.003)\end{array}$ & $\begin{array}{l}-0.004 \\
(0.003)\end{array}$ & $\begin{array}{l}-0.004 \\
(0.003)\end{array}$ \\
\hline firm_exports & & $\begin{array}{c}1.253 \\
(1.105)\end{array}$ & $\begin{array}{c}1.183 \\
(1.145)\end{array}$ & $\begin{array}{c}1.278 \\
(1.171)\end{array}$ & & $\begin{array}{l}2.467^{*} \\
(1.089)\end{array}$ & $\begin{array}{l}2.449^{*} \\
(1.090)\end{array}$ & $\begin{array}{l}2.483^{*} \\
(1.076)\end{array}$ \\
\hline $\begin{array}{l}\text { firm_industry_ } \\
\text { restact }\end{array}$ & & $\begin{array}{l}-1.613 \\
(1.336)\end{array}$ & $\begin{array}{l}-1.588 \\
(1.330)\end{array}$ & $\begin{array}{l}-1.718 \\
(1.305)\end{array}$ & & $\begin{array}{c}0.329 \\
(0.505)\end{array}$ & $\begin{array}{c}0.322 \\
(0.507)\end{array}$ & $\begin{array}{c}0.281 \\
(0.483)\end{array}$ \\
\hline $\begin{array}{l}\text { firm_industry_ } \\
\text { low }\end{array}$ & & $\begin{array}{l}-0.628 \\
(1.023)\end{array}$ & $\begin{array}{l}-0.840 \\
(1.021)\end{array}$ & $\begin{array}{l}-0.638 \\
(1.043)\end{array}$ & & $\begin{array}{c}0.170 \\
(0.612)\end{array}$ & $\begin{array}{c}0.154 \\
(0.629)\end{array}$ & $\begin{array}{c}0.118 \\
(0.637)\end{array}$ \\
\hline $\begin{array}{l}\text { firm_industry_ } \\
\text { mlow }\end{array}$ & & $\begin{array}{l}-0.534 \\
(1.416)\end{array}$ & $\begin{array}{l}-0.545 \\
(1.407)\end{array}$ & $\begin{array}{l}-0.590 \\
(1.402)\end{array}$ & & $\begin{array}{c}0.608 \\
(0.517)\end{array}$ & $\begin{array}{c}0.640 \\
(0.507)\end{array}$ & $\begin{array}{c}0.624 \\
(0.515)\end{array}$ \\
\hline $\begin{array}{l}\text { firm_industry_ } \\
\text { mhigh }\end{array}$ & & $\begin{array}{l}-0.614 \\
(0.908)\end{array}$ & $\begin{array}{l}-0.683 \\
(0.899)\end{array}$ & $\begin{array}{l}-0.621 \\
(0.901)\end{array}$ & & $\begin{array}{c}0.081 \\
(0.428)\end{array}$ & $\begin{array}{c}0.093 \\
(0.427)\end{array}$ & $\begin{array}{c}0.055 \\
(0.421)\end{array}$ \\
\hline $\begin{array}{l}\text { firm_industry_ } \\
\text { kis }\end{array}$ & & $\begin{array}{l}-1.019 \\
(0.770)\end{array}$ & $\begin{array}{l}-1.053 \\
(0.757)\end{array}$ & $\begin{array}{l}-1.126 \\
(0.760)\end{array}$ & & $\begin{array}{c}0.163 \\
(0.234)\end{array}$ & $\begin{array}{c}0.158 \\
(0.232)\end{array}$ & $\begin{array}{c}0.146 \\
(0.226)\end{array}$ \\
\hline $\begin{array}{l}\text { firm_industry_ } \\
\text { nkis }\end{array}$ & & $\begin{array}{l}-0.518 \\
(0.851)\end{array}$ & $\begin{array}{l}-0.590 \\
(0.867)\end{array}$ & $\begin{array}{l}-0.593 \\
(0.867)\end{array}$ & & $\begin{array}{l}-0.148 \\
(0.307)\end{array}$ & $\begin{array}{l}-0.167 \\
(0.305)\end{array}$ & $\begin{array}{l}-0.210 \\
(0.299)\end{array}$ \\
\hline $\begin{array}{l}\text { firm_innov_ef } \\
\text { fort }\end{array}$ & & $\begin{array}{l}0.387^{* * * *} \\
(0.043)\end{array}$ & $\begin{array}{l}0.391^{* * *} \\
(0.042)\end{array}$ & $\begin{array}{l}0.389^{* * *} \\
(0.042)\end{array}$ & & $\begin{array}{l}0.169^{* * * *} \\
(0.015)\end{array}$ & $\begin{array}{l}0.170^{* * *} \\
(0.015)\end{array}$ & $\begin{array}{l}0.167^{* * *} \\
(0.014)\end{array}$ \\
\hline firm_costobst & & $\begin{array}{c}1.065 \\
(0.862)\end{array}$ & $\begin{array}{c}1.045 \\
(0.842)\end{array}$ & $\begin{array}{c}1.021 \\
(0.860)\end{array}$ & & $\begin{array}{l}-0.125 \\
(0.398)\end{array}$ & $\begin{array}{l}-0.142 \\
(0.389)\end{array}$ & $\begin{array}{l}-0.177 \\
(0.401)\end{array}$ \\
\hline firm_infobst & & $\begin{array}{c}0.824 \\
(1.276)\end{array}$ & $\begin{array}{c}0.589 \\
(1.248)\end{array}$ & $\begin{array}{c}0.583 \\
(1.256)\end{array}$ & & $\begin{array}{l}-0.136 \\
(0.693)\end{array}$ & $\begin{array}{l}-0.149 \\
(0.690)\end{array}$ & $\begin{array}{l}-0.149 \\
(0.721)\end{array}$ \\
\hline lfirm_age & & $\begin{array}{l}0.856^{* *} \\
(0.229)\end{array}$ & $\begin{array}{l}0.835^{* * *} \\
(0.227)\end{array}$ & $\begin{array}{l}0.830^{* * *} \\
(0.228)\end{array}$ & & $\begin{array}{c}0.094 \\
(0.137)\end{array}$ & $\begin{array}{c}0.090 \\
(0.135)\end{array}$ & $\begin{array}{c}0.075 \\
(0.142)\end{array}$ \\
\hline gdp_prov & & $\begin{array}{l}-0.480 \\
(0.831)\end{array}$ & $\begin{array}{l}-1.073 \\
(0.566)\end{array}$ & $\begin{array}{l}-1.263^{* *} \\
(0.448)\end{array}$ & & $\begin{array}{c}0.297 \\
(0.480)\end{array}$ & $\begin{array}{c}0.175 \\
(0.720)\end{array}$ & $\begin{array}{c}0.340 \\
(0.611)\end{array}$ \\
\hline park_age & & & $\begin{array}{l}-0.493^{* *} \\
(0.140)\end{array}$ & $\begin{array}{c}-0.716^{* * * *} \\
(0.115)\end{array}$ & & & $\begin{array}{l}-0.036 \\
(0.157)\end{array}$ & $\begin{array}{l}-0.070 \\
(0.154)\end{array}$ \\
\hline park_agesq & & & $\begin{array}{l}0.016^{* * *} \\
(0.005)\end{array}$ & $\begin{array}{l}0.022^{* * * *} \\
(0.004)\end{array}$ & & & $\begin{array}{c}0.002 \\
(0.005)\end{array}$ & $\begin{array}{c}0.002 \\
(0.005)\end{array}$ \\
\hline lpark_firms & & & $\begin{array}{l}0.345^{* *} \\
(0.119)\end{array}$ & $\begin{array}{l}0.462^{* * *} \\
(0.130)\end{array}$ & & & $\begin{array}{c}0.061 \\
(0.102)\end{array}$ & $\begin{array}{c}0.112 \\
(0.107)\end{array}$ \\
\hline lpark_staff & & & & $\begin{array}{l}0.472^{\text {**** }} \\
(0.106)\end{array}$ & & & & $\begin{array}{c}0.040 \\
(0.135)\end{array}$ \\
\hline $\begin{array}{l}\text { park_services__ } \\
\text { i }\end{array}$ & & & & $\begin{array}{c}0.338 \\
(0.207)\end{array}$ & & & & $\begin{array}{l}-0.304 \\
(0.252)\end{array}$ \\
\hline $\begin{array}{l}\text { park_services_ } \\
\text { c }\end{array}$ & & & & $\begin{array}{l}-0.668 \\
(0.376)\end{array}$ & & & & $\begin{array}{l}-0.076 \\
(0.301)\end{array}$ \\
\hline$N$ & 849 & 849 & 849 & 849 & 849 & 849 & 849 & 849 \\
\hline
\end{tabular}

Marginal effects; Standard errors in parentheses are clustered by park. VIF test shows no multicollinearity problems.

${ }^{*} p<0.05,{ }^{* *} p<0.01,{ }^{* * *} p<0.001$ 
Columns V-VIII present the four specifications for the dependent variable lpatents, all of which provide very similar results. Firms in Pure Science Parks achieve a higher number of patents than firms in other park types. Again, the differences are large in magnitude, between 135 and $144 \log$ points (approximately four times more patents per employee).

Among firm covariates, results are again very robust to the inclusion of STP characteristics. Innovation effort is the most significant. We also observe a positive effect of exports, but no significant effect of size, industry technology level or obstacles to innovation. Therefore, park characteristics do not explain firm patenting.

These results from tables 8 and 9 show a clear output specialization for different park types. Firms in Pure Science Parks show the highest performance in patenting, but perform worst for sales of new products, while Pure Technology Park firms (no university presence) show the opposite pattern. Firms in Mixed Parks and Technology Parks with a University are somewhere between these two extremes.

\subsubsection{An additional check for omitted variable bias}

We include in the specifications a large set of firm covariates in order that the effect of park type is not confounded by the influence of orientation of firms' innovation processes. These covariates may capture some degree of the heterogeneity of the innovation processes, but it could be argued that the firm's specific innovation orientation (more or less scientific) is not adequately captured. This is important because some studies have shown that those firms more scientific oriented show (all else equal) less sales from new products, but a similar number of patents (Barge-Gil and López, 2015).

In addition, Science Parks would probably attract more scientific oriented firms while Technology Parks would attract less scientific oriented firms. Accordingly, it is very important to rule out the possibility that previous results are just a reflection of scientific orientation of firms instead of the type of Park they belong to. This is the purpose of this subsection. Tables 9 and 10 include the covariate $\mathrm{PhDs}$ (percentage of $\mathrm{R} \& \mathrm{D}$ employees with a $\mathrm{PhD}$ degree) to proxy for the scientific orientation of the firm. We did not include this covariate in the main analysis because we observe it only for those firms with a formal R\&D department, ${ }^{23}$ which reduces our sample of on-park firms to 667 (78.6\% of the 849 firms in the full sample). ${ }^{24}$ We deal with reduction in firms in two ways. First, Table 9 assumes that firms with no R\&D department are

\footnotetext{
${ }^{23}$ Around $50 \%$ of Spanish innovative firms do not have an R\&D department. They achieve new products and processes from the development of other innovation activities, e.g. design (Barge-Gil et al., 2011a).

${ }^{24}$ Based on park type, firms with formal R\&D functions are 101 out of 112 firms $(90.2 \%)$ in Pure Science Parks, 167 out of $206(81.1 \%)$ in Mixed Parks, 213 out of 260 (81.9\%) in Technology Parks with University and 186 out of 271 (68.6\%) in Pure Technology Parks.
} 
not scientifically oriented and, accordingly, we assign them zero percentage of $\mathrm{PhDs}^{25}$ in the $\mathrm{R} \& \mathrm{D}$ team. In this case, we include an additional covariate, int_R\&D, which is a dummy variable that takes the value 1 if the firm conducts $R \& D$, and zero otherwise. Second, Table 10 estimates the model on the smaller sample.

The main results do not change significantly in any of these estimations, despite the percentage of $\mathrm{PhDs}$ showing a positive effect on patents and a negative (non-significant) effect on products. In addition, when our preferred specifications, controlling for the whole set of park characteristics (Tables 9 and 10, Columns II and IV) are examined, the magnitude of the effects is very similar to those presented in Table 8. Accordingly, it seems that the different performance of firms located in different types of parks are, at least to some extent, a consequence of the role played by the type of park rather than differences in the firms located in them.

Pure Science Parks seem able to foster higher levels of firm patenting. This result can be interpreted in different ways. On the one hand, patenting could be regarded as a first step towards more marketable results. On the other hand, most patents never materialize into new products; a great deal of effort is required to transform a patent into an economic success (Chesbrough, 2003).

\footnotetext{
${ }^{25}$ As expected, we find that firms in Pure Science Parks have a higher share of R\&D personnel with a $\mathrm{PhD}$ degree. The mean values for this variable according to park type are: 0.25 for Pure Science Parks, 0.14 for Mixed Parks, 0.08 for Technology Parks with University and 0.08 for Pure Technology Parks.
} 
Table 9. Influence of park type on innovation outputs (Includes Phd. Full Sample).

\begin{tabular}{|c|c|c|c|c|}
\hline & $\begin{array}{c}\text { (I) } \\
\text { lnew_prod }\end{array}$ & $\begin{array}{c}\text { (II) } \\
\text { lnew_prod }\end{array}$ & $\begin{array}{c}\text { (III) } \\
\text { lpatnuml }\end{array}$ & $\begin{array}{c}\text { (IV) } \\
\text { lpatnuml }\end{array}$ \\
\hline Pure_Science_Park & $\begin{array}{l}-0.540 \\
(0.340)\end{array}$ & $\begin{array}{c}-1.048^{* *} \\
(0.353)\end{array}$ & $\begin{array}{l}1.167^{* * *} \\
(0.371)\end{array}$ & $\begin{array}{l}1.193^{* *} \\
(0.379)\end{array}$ \\
\hline Mixed_Park & $\begin{array}{l}-0.938^{*} \\
(0.353)\end{array}$ & $\begin{array}{l}-0.856^{* *} \\
(0.271)\end{array}$ & $\begin{array}{l}-0.128 \\
(0.311)\end{array}$ & $\begin{array}{c}0.002 \\
(0.343)\end{array}$ \\
\hline Tech_Park_with_University & $\begin{array}{c}-0.544 \\
(0.313)\end{array}$ & $\begin{array}{l}-0.315 \\
(0.241)\end{array}$ & $\begin{array}{c}0.064 \\
(0.299)\end{array}$ & $\begin{array}{c}0.014 \\
(0.293)\end{array}$ \\
\hline lfirm_sales & $\begin{array}{c}0.133 \\
(0.097)\end{array}$ & $\begin{array}{c}0.131 \\
(0.098)\end{array}$ & $\begin{array}{l}-0.000 \\
(0.058)\end{array}$ & $\begin{array}{c}-0.004 \\
(0.056)\end{array}$ \\
\hline lfirm_sales_q & $\begin{array}{l}-0.007 \\
(0.007)\end{array}$ & $\begin{array}{l}-0.007 \\
(0.007)\end{array}$ & $\begin{array}{l}-0.002 \\
(0.003)\end{array}$ & $\begin{array}{l}-0.002 \\
(0.003)\end{array}$ \\
\hline firm_exports & $\begin{array}{c}1.385 \\
(1.143)\end{array}$ & $\begin{array}{c}1.499 \\
(1.179)\end{array}$ & $\begin{array}{c}2.174 \\
(1.101)\end{array}$ & $\begin{array}{c}2.200 \\
(1.091)\end{array}$ \\
\hline firm_industry_restact & $\begin{array}{c}-1.611 \\
(1.312)\end{array}$ & $\begin{array}{l}-1.748 \\
(1.283)\end{array}$ & $\begin{array}{c}0.384 \\
(0.505)\end{array}$ & $\begin{array}{c}0.352 \\
(0.485)\end{array}$ \\
\hline firm_industry_low & $\begin{array}{c}-0.806 \\
(1.022)\end{array}$ & $\begin{array}{l}-0.587 \\
(1.053)\end{array}$ & $\begin{array}{c}0.112 \\
(0.659)\end{array}$ & $\begin{array}{c}0.070 \\
(0.671)\end{array}$ \\
\hline firm_industry_mlow & $\begin{array}{c}-0.556 \\
(1.452)\end{array}$ & $\begin{array}{l}-0.578 \\
(1.451)\end{array}$ & $\begin{array}{c}0.750 \\
(0.516)\end{array}$ & $\begin{array}{c}0.719 \\
(0.527)\end{array}$ \\
\hline firm_industry_mhigh & $\begin{array}{l}-0.651 \\
(0.912)\end{array}$ & $\begin{array}{l}-0.578 \\
(0.920)\end{array}$ & $\begin{array}{c}0.067 \\
(0.449)\end{array}$ & $\begin{array}{c}0.027 \\
(0.445)\end{array}$ \\
\hline firm_industry_kis & $\begin{array}{l}-1.009 \\
(0.743)\end{array}$ & $\begin{array}{l}-1.085 \\
(0.742)\end{array}$ & $\begin{array}{c}0.126 \\
(0.238)\end{array}$ & $\begin{array}{c}0.120 \\
(0.235)\end{array}$ \\
\hline firm_industry_nkis & $\begin{array}{l}-0.558 \\
(0.845)\end{array}$ & $\begin{array}{l}-0.569 \\
(0.842)\end{array}$ & $\begin{array}{l}-0.241 \\
(0.307)\end{array}$ & $\begin{array}{c}-0.271 \\
(0.304)\end{array}$ \\
\hline firm_innov_effort & $\begin{array}{l}0.402^{*} \\
(0.145)\end{array}$ & $\begin{array}{l}0.411^{* *} \\
(0.145)\end{array}$ & $\begin{array}{l}0.282^{* * * *} \\
(0.064)\end{array}$ & $\begin{array}{l}0.275^{\text {**** }} \\
(0.064)\end{array}$ \\
\hline PhDs & $\begin{array}{l}-1.763 \\
(1.092)\end{array}$ & $\begin{array}{l}-1.883 \\
(1.104)\end{array}$ & $\begin{array}{l}2.153^{* *} \\
(0.681)\end{array}$ & $\begin{array}{l}2.164^{* *} \\
(0.688)\end{array}$ \\
\hline int_R\&D & $\begin{array}{c}0.092 \\
(1.479)\end{array}$ & $\begin{array}{l}-0.016 \\
(1.460)\end{array}$ & $\begin{array}{l}-1.429^{*} \\
(0.573)\end{array}$ & $\begin{array}{l}-1.367^{*} \\
(0.576)\end{array}$ \\
\hline firm_costobst & $\begin{array}{c}0.996 \\
(0.891)\end{array}$ & $\begin{array}{c}0.958 \\
(0.910)\end{array}$ & $\begin{array}{c}-0.070 \\
(0.383)\end{array}$ & $\begin{array}{c}-0.091 \\
(0.393)\end{array}$ \\
\hline firm_infobst & $\begin{array}{c}0.560 \\
(1.257)\end{array}$ & $\begin{array}{c}0.575 \\
(1.256)\end{array}$ & $\begin{array}{c}-0.076 \\
(0.775)\end{array}$ & $\begin{array}{c}-0.095 \\
(0.806)\end{array}$ \\
\hline lfirm_age & $\begin{array}{l}0.826^{* * * *} \\
(0.220)\end{array}$ & $\begin{array}{l}0.822^{* * *} \\
(0.221)\end{array}$ & $\begin{array}{c}0.149 \\
(0.140)\end{array}$ & $\begin{array}{c}0.137 \\
(0.147)\end{array}$ \\
\hline lgdp_prov & $\begin{array}{l}-1.046 \\
(0.589)\end{array}$ & $\begin{array}{c}-1.228^{* *} \\
(0.405)\end{array}$ & $\begin{array}{c}0.015 \\
(0.660)\end{array}$ & $\begin{array}{c}0.150 \\
(0.578)\end{array}$ \\
\hline park_age & $\begin{array}{l}-0.486^{* * *} \\
(0.144)\end{array}$ & $\begin{array}{c}-0.720^{* * * *} \\
(0.103)\end{array}$ & $\begin{array}{l}-0.052 \\
(0.147)\end{array}$ & $\begin{array}{c}-0.075 \\
(0.147)\end{array}$ \\
\hline park_agesq & $\begin{array}{l}0.016^{* * *} \\
(0.005)\end{array}$ & $\begin{array}{c}0.023^{* * *} \\
(0.003)\end{array}$ & $\begin{array}{c}0.002 \\
(0.005)\end{array}$ & $\begin{array}{c}0.002 \\
(0.005)\end{array}$ \\
\hline lpark_firms & $\begin{array}{l}0.351^{\text {** }} \\
(0.115)\end{array}$ & $\begin{array}{c}0.497^{\text {**** }} \\
(0.125)\end{array}$ & $\begin{array}{c}0.058 \\
(0.100)\end{array}$ & $\begin{array}{c}0.080 \\
(0.105)\end{array}$ \\
\hline lpark_staff & & $\begin{array}{l}0.503^{* * *} \\
(0.093)\end{array}$ & & $\begin{array}{c}0.015 \\
(0.124)\end{array}$ \\
\hline park_services_i & & $\begin{array}{c}0.297 \\
(0.201)\end{array}$ & & $\begin{array}{c}-0.230 \\
(0.249)\end{array}$ \\
\hline park_services_c & & $\begin{array}{l}-0.579 \\
(0.331)\end{array}$ & & $\begin{array}{c}-0.151 \\
(0.288)\end{array}$ \\
\hline$N$ & 849 & 849 & 849 & 849 \\
\hline
\end{tabular}

Marginal effects; Standard errors in parentheses are clustered by park. Reference park type is Pure Technology Park. VIF test shows no multicollinearity problems.

${ }^{*} p<0.05,{ }^{* *} p<0.01,{ }^{* * *} p<0.001$ 
Table 10. Influence of park type on innovation outputs (Includes Phd. Restricted Sample).

\begin{tabular}{|c|c|c|c|c|}
\hline & $\begin{array}{c}\text { (I) } \\
\text { lnew_prod }\end{array}$ & $\begin{array}{c}\text { (II) } \\
\text { lnew_prod }\end{array}$ & $\begin{array}{c}\text { (III) } \\
\text { lpatnuml }\end{array}$ & $\begin{array}{c}\text { (IV) } \\
\text { lpatnuml }\end{array}$ \\
\hline Pure_Science_Park & $\begin{array}{c}-0.954 \\
(0.468)\end{array}$ & $\begin{array}{c}-1.404^{* *} \\
(0.409)\end{array}$ & $\begin{array}{l}1.006^{*} \\
(0.423)\end{array}$ & $\begin{array}{c}1.086^{*} \\
(0.410)\end{array}$ \\
\hline Mixed_Park & $\begin{array}{c}-1.465^{* * * *} \\
(0.380)\end{array}$ & $\begin{array}{c}-1.275^{* * * *} \\
(0.280)\end{array}$ & $\begin{array}{l}-0.232 \\
(0.395)\end{array}$ & $\begin{array}{l}-0.159 \\
(0.431)\end{array}$ \\
\hline Tech_Park_with_University & $\begin{array}{l}-0.709 \\
(0.416)\end{array}$ & $\begin{array}{l}-0.506 \\
(0.302)\end{array}$ & $\begin{array}{c}0.094 \\
(0.339)\end{array}$ & $\begin{array}{l}-0.002 \\
(0.352)\end{array}$ \\
\hline lfirm_sales & $\begin{array}{c}0.182 \\
(0.104)\end{array}$ & $\begin{array}{c}0.185 \\
(0.103)\end{array}$ & $\begin{array}{l}-0.045 \\
(0.063)\end{array}$ & $\begin{array}{l}-0.050 \\
(0.062)\end{array}$ \\
\hline lfirm_sales_q & $\begin{array}{l}-0.009 \\
(0.007)\end{array}$ & $\begin{array}{l}-0.009 \\
(0.007)\end{array}$ & $\begin{array}{c}0.001 \\
(0.003)\end{array}$ & $\begin{array}{c}0.001 \\
(0.003)\end{array}$ \\
\hline firm_exports & $\begin{array}{c}0.017 \\
(1.586)\end{array}$ & $\begin{array}{c}0.231 \\
(1.635)\end{array}$ & $\begin{array}{c}2.007 \\
(1.376)\end{array}$ & $\begin{array}{c}2.047 \\
(1.357)\end{array}$ \\
\hline firm_industry_restact & $\begin{array}{l}-1.333 \\
(1.824)\end{array}$ & $\begin{array}{l}-1.446 \\
(1.771)\end{array}$ & $\begin{array}{c}0.974 \\
(0.769)\end{array}$ & $\begin{array}{c}0.963 \\
(0.757)\end{array}$ \\
\hline firm_industry_low & $\begin{array}{c}0.838 \\
(1.476)\end{array}$ & $\begin{array}{c}0.992 \\
(1.492)\end{array}$ & $\begin{array}{c}0.317 \\
(0.955)\end{array}$ & $\begin{array}{c}0.311 \\
(0.969)\end{array}$ \\
\hline firm_industry_mlow & $\begin{array}{l}-0.660 \\
(1.662)\end{array}$ & $\begin{array}{l}-0.704 \\
(1.666)\end{array}$ & $\begin{array}{l}1.333^{*} \\
(0.639)\end{array}$ & $\begin{array}{c}1.290 \\
(0.663)\end{array}$ \\
\hline firm_industry_mhigh & $\begin{array}{l}-0.763 \\
(1.053)\end{array}$ & $\begin{array}{l}-0.744 \\
(1.054)\end{array}$ & $\begin{array}{c}0.517 \\
(0.542)\end{array}$ & $\begin{array}{c}0.453 \\
(0.539)\end{array}$ \\
\hline firm_industry_kis & $\begin{array}{l}-0.766 \\
(0.919)\end{array}$ & $\begin{array}{l}-0.831 \\
(0.922)\end{array}$ & $\begin{array}{c}0.356 \\
(0.287)\end{array}$ & $\begin{array}{c}0.356 \\
(0.287)\end{array}$ \\
\hline firm_industry_nkis & $\begin{array}{l}-0.415 \\
(1.273)\end{array}$ & $\begin{array}{l}-0.421 \\
(1.284)\end{array}$ & $\begin{array}{l}-0.176 \\
(0.505)\end{array}$ & $\begin{array}{l}-0.189 \\
(0.506)\end{array}$ \\
\hline firm_innov_effort & $\begin{array}{l}0.591^{* *} \\
(0.174)\end{array}$ & $\begin{array}{l}0.579^{* *} \\
(0.173)\end{array}$ & $\begin{array}{l}0.574^{* * * *} \\
(0.084)\end{array}$ & $\begin{array}{l}0.563^{* * * *} \\
(0.085)\end{array}$ \\
\hline PhDs & $\begin{array}{l}-1.739 \\
(1.043)\end{array}$ & $\begin{array}{l}-1.863 \\
(1.052)\end{array}$ & $\begin{array}{l}1.836^{*} \\
(0.691)\end{array}$ & $\begin{array}{l}1.885^{*} \\
(0.718)\end{array}$ \\
\hline firm_costobst & $\begin{array}{c}0.378 \\
(1.132)\end{array}$ & $\begin{array}{c}0.374 \\
(1.147)\end{array}$ & $\begin{array}{c}-0.045 \\
(0.550)\end{array}$ & $\begin{array}{c}-0.060 \\
(0.555)\end{array}$ \\
\hline firm_infobst & $\begin{array}{c}0.767 \\
(1.320)\end{array}$ & $\begin{array}{c}0.756 \\
(1.340)\end{array}$ & $\begin{array}{c}-0.126 \\
(0.953)\end{array}$ & $\begin{array}{c}-0.166 \\
(0.982)\end{array}$ \\
\hline lfirm_age & $\begin{array}{c}0.997^{*} \\
(0.362)\end{array}$ & $\begin{array}{l}1.000^{*} \\
(0.359)\end{array}$ & $\begin{array}{c}0.182 \\
(0.177)\end{array}$ & $\begin{array}{c}0.171 \\
(0.179)\end{array}$ \\
\hline lgdp_prov & $\begin{array}{l}-2.024^{* * *} \\
(0.706)\end{array}$ & $\begin{array}{c}-1.994^{* * * *} \\
(0.497)\end{array}$ & $\begin{array}{c}-0.383 \\
(0.774)\end{array}$ & $\begin{array}{c}-0.272 \\
(0.674)\end{array}$ \\
\hline park_age & $\begin{array}{c}-0.721^{* * * *} \\
(0.150)\end{array}$ & $\begin{array}{c}-0.949^{* * *} \\
(0.106)\end{array}$ & $\begin{array}{l}-0.120 \\
(0.164)\end{array}$ & $\begin{array}{c}-0.143 \\
(0.160)\end{array}$ \\
\hline park_agesq & $\begin{array}{c}0.024^{* * *} \\
(0.005)\end{array}$ & $\begin{array}{l}0.030^{\text {**** }} \\
(0.004)\end{array}$ & $\begin{array}{c}0.004 \\
(0.006)\end{array}$ & $\begin{array}{c}0.004 \\
(0.005)\end{array}$ \\
\hline lpark_firms & $\begin{array}{c}0.409^{*} \\
(0.184)\end{array}$ & $\begin{array}{l}0.592^{* *} \\
(0.159)\end{array}$ & $\begin{array}{c}0.095 \\
(0.131)\end{array}$ & $\begin{array}{c}0.081 \\
(0.141)\end{array}$ \\
\hline lpark_staff & & $\begin{array}{c}0.552^{* * * *} \\
(0.135)\end{array}$ & & $\begin{array}{c}-0.020 \\
(0.177)\end{array}$ \\
\hline park_services_i & & $\begin{array}{c}0.167 \\
(0.268)\end{array}$ & & $\begin{array}{c}-0.194 \\
(0.288)\end{array}$ \\
\hline park_services_c & & $\begin{array}{c}-0.757 \\
(0.383)\end{array}$ & & $\begin{array}{c}-0.260 \\
(0.350)\end{array}$ \\
\hline$N$ & 667 & 667 & 667 & 667 \\
\hline
\end{tabular}

Marginal effects; Standard errors in parentheses are clustered by park. Reference park type is Pure Technology Park. VIF test shows no multicollinearity problems.

${ }^{*} p<0.05,{ }^{* *} p<0.01,{ }^{* * *} p<0.001$

\subsection{Influence of park type on links with universities}

A different and interesting question is whether the relationships between firms and universities are stronger for firms in Science Parks, considering that one of the main objectives of Science 
Parks is to foster university-industry relationships (Minguillo et al., 2015). We analyse two dependent variables: existence of cooperation, coop_uni, and purchase of university R\&D, $R \& D$. Table 11 presents the first set of results. Columns I and $\mathrm{V}$ provide a comparison across park types, showing a higher likelihood of cooperation with universities for Mixed Parks compared to Pure Technology Parks, and no significant differences regarding bought-in R\&D. The specifications in Columns II and VI include firms' characteristics and show no significant differences across STPs types for cooperation with universities, but higher levels of externally sourced R\&D for Pure Science Parks than Pure Technology Parks. Columns III and VII include park age and size, but show no statistically significant differences across park types, although the coefficient of Pure Science Parks is still large. Finally, columns IV and VIII include park's management characteristics; again, there are no statistically significant differences across park types.

To sum up, we find no evidence that Pure Science Parks and Mixed Parks fostering the likelihood of cooperation with universities when firms' characteristics are controlled for. When external R\&D is analysed, the coefficient of Pure Science Parks is always positive and quite large, although it is significant only in column VI which does not account for park characteristics.

Regarding the covariates, we find a significant effect of innovation effort, industry technological level and level of development in the province. This last effect is negative, indicating that firms in more developed provinces are less likely to cooperate with universities, and less likely to buy in university R\&D. ${ }^{26}$ No significant effect is found for size, exports or obstacles to innovation, while age shows a positive effect, which is significant in the cooperation equation, but not in the equation for external R\&D.

\footnotetext{
${ }^{26}$ This is probably due to the fact that more developed provinces have more varied supply of $R \& D$ partners that also includes private companies. Also, technology institutes are important providers of external R\&D to firms and they have a high presence in some richer provinces, such as those in the Basque Country and Navarra (Barge-Gil et al., 2011b).
} 
Table 11. Influence of park type on links with universities. Main Specification.

\begin{tabular}{|c|c|c|c|c|c|c|c|c|}
\hline & $\begin{array}{c}\text { (I) } \\
\text { coop_uni }\end{array}$ & $\begin{array}{c}\text { (II) } \\
\text { coop_uni }\end{array}$ & $\begin{array}{c}\text { (III) } \\
\text { coop_uni }\end{array}$ & $\begin{array}{c}\text { (IV) } \\
\text { coop_uni }\end{array}$ & $\begin{array}{c}(\mathrm{V}) \\
\mathrm{R} \& \mathrm{D}\end{array}$ & $\begin{array}{l}\text { (VI) } \\
\text { R\&D }\end{array}$ & $\begin{array}{l}\text { (VII) } \\
\text { R\&D }\end{array}$ & $\begin{array}{l}\text { (VIII) } \\
\text { R\&D }\end{array}$ \\
\hline Pure_Science_Park & $\begin{array}{c}0.096 \\
(0.080)\end{array}$ & $\begin{array}{c}0.026 \\
(0.057)\end{array}$ & $\begin{array}{l}-0.006 \\
(0.057)\end{array}$ & $\begin{array}{l}-0.034 \\
(0.067)\end{array}$ & $\begin{array}{c}1.227 \\
(0.609)\end{array}$ & $\begin{array}{l}0.957^{*} \\
(0.435)\end{array}$ & $\begin{array}{c}0.902 \\
(0.447)\end{array}$ & $\begin{array}{c}1.078 \\
(0.596)\end{array}$ \\
\hline Mixed_Park & $\begin{array}{l}0.120 * \\
(0.048)\end{array}$ & $\begin{array}{c}0.056 \\
(0.040)\end{array}$ & $\begin{array}{c}0.048 \\
(0.039)\end{array}$ & $\begin{array}{c}0.026 \\
(0.036)\end{array}$ & $\begin{array}{c}0.454 \\
(0.308)\end{array}$ & $\begin{array}{c}0.070 \\
(0.257)\end{array}$ & $\begin{array}{c}0.109 \\
(0.466)\end{array}$ & $\begin{array}{l}-0.200 \\
(0.458)\end{array}$ \\
\hline $\begin{array}{l}\text { Tech_Park_with_ } \\
\text { University }\end{array}$ & $\begin{array}{c}0.051 \\
(0.049)\end{array}$ & $\begin{array}{l}-0.006 \\
(0.043)\end{array}$ & $\begin{array}{c}0.010 \\
(0.031)\end{array}$ & $\begin{array}{c}0.031 \\
(0.030)\end{array}$ & $\begin{array}{c}0.263 \\
(0.302)\end{array}$ & $\begin{array}{c}0.006 \\
(0.240)\end{array}$ & $\begin{array}{c}0.053 \\
(0.224)\end{array}$ & $\begin{array}{c}0.078 \\
(0.215)\end{array}$ \\
\hline lfirm_sales & & $\begin{array}{l}-0.001 \\
(0.011)\end{array}$ & $\begin{array}{l}-0.002 \\
(0.011)\end{array}$ & $\begin{array}{l}-0.002 \\
(0.011)\end{array}$ & & $\begin{array}{c}0.008 \\
(0.069)\end{array}$ & $\begin{array}{c}0.002 \\
(0.070)\end{array}$ & $\begin{array}{l}-0.002 \\
(0.069)\end{array}$ \\
\hline lfirm_sales_q & & $\begin{array}{c}0.001 \\
(0.001)\end{array}$ & $\begin{array}{c}0.001 \\
(0.001)\end{array}$ & $\begin{array}{c}0.001 \\
(0.001)\end{array}$ & & $\begin{array}{c}0.001 \\
(0.004)\end{array}$ & $\begin{array}{c}0.002 \\
(0.004)\end{array}$ & $\begin{array}{c}0.002 \\
(0.004)\end{array}$ \\
\hline firm_exports & & $\begin{array}{c}0.054 \\
(0.153)\end{array}$ & $\begin{array}{c}0.054 \\
(0.154)\end{array}$ & $\begin{array}{c}0.056 \\
(0.152)\end{array}$ & & $\begin{array}{c}1.769 \\
(1.061)\end{array}$ & $\begin{array}{c}1.778 \\
(1.090)\end{array}$ & $\begin{array}{c}1.724 \\
(1.091)\end{array}$ \\
\hline firm_industry_restact & & $\begin{array}{l}-0.195^{*} \\
(0.075)\end{array}$ & $\begin{array}{l}-0.184^{*} \\
(0.075)\end{array}$ & $\begin{array}{l}-0.188^{*} \\
(0.075)\end{array}$ & & $\begin{array}{c}-0.818 \\
(0.442)\end{array}$ & $\begin{array}{l}-0.786 \\
(0.446)\end{array}$ & $\begin{array}{l}-0.727 \\
(0.442)\end{array}$ \\
\hline firm_industry_low & & $\begin{array}{l}-0.166 \\
(0.089)\end{array}$ & $\begin{array}{l}-0.178 \\
(0.092)\end{array}$ & $\begin{array}{l}-0.157 \\
(0.089)\end{array}$ & & $\begin{array}{l}-0.449 \\
(0.478)\end{array}$ & $\begin{array}{l}-0.456 \\
(0.486)\end{array}$ & $\begin{array}{l}-0.404 \\
(0.489)\end{array}$ \\
\hline firm_industry_mlow & & $\begin{array}{l}-0.238^{*} \\
(0.108)\end{array}$ & $\begin{array}{l}-0.263^{*} \\
(0.103)\end{array}$ & $\begin{array}{l}-0.265^{*} \\
(0.102)\end{array}$ & & $\begin{array}{l}-1.178^{*} \\
(0.492)\end{array}$ & $\begin{array}{l}-1.254^{*} \\
(0.455)\end{array}$ & $\begin{array}{l}-1.283^{*} \\
(0.469)\end{array}$ \\
\hline firm_industry_mhigh & & $\begin{array}{c}-0.289^{* * * *} \\
(0.054)\end{array}$ & $\begin{array}{c}-0.305^{* * *} \\
(0.056)\end{array}$ & $\begin{array}{c}-0.295^{* * * *} \\
(0.054)\end{array}$ & & $\begin{array}{c}-1.252^{* *} \\
(0.361)\end{array}$ & $\begin{array}{l}-1.293^{* *} \\
(0.371)\end{array}$ & $\begin{array}{c}-1.246^{* * *} \\
(0.380)\end{array}$ \\
\hline firm_industry_kis & & $\begin{array}{l}-0.057 \\
(0.059)\end{array}$ & $\begin{array}{l}-0.053 \\
(0.058)\end{array}$ & $\begin{array}{l}-0.056 \\
(0.058)\end{array}$ & & $\begin{array}{l}-0.591 \\
(0.396)\end{array}$ & $\begin{array}{l}-0.570 \\
(0.402)\end{array}$ & $\begin{array}{l}-0.542 \\
(0.404)\end{array}$ \\
\hline firm_industry_nkis & & $\begin{array}{c}-0.219^{* * *} \\
(0.059)\end{array}$ & $\begin{array}{l}-0.209^{* *} \\
(0.058)\end{array}$ & $\begin{array}{l}-0.203^{* * *} \\
(0.059)\end{array}$ & & $\begin{array}{c}-1.107^{* *} \\
(0.394)\end{array}$ & $\begin{array}{l}-1.066^{*} \\
(0.400)\end{array}$ & $\begin{array}{l}-0.983^{*} \\
(0.394)\end{array}$ \\
\hline firm_innov_effort & & $\begin{array}{l}0.041^{* * * *} \\
(0.004)\end{array}$ & $\begin{array}{l}0.041^{* * * *} \\
(0.004)\end{array}$ & $\begin{array}{l}0.041^{* * *} \\
(0.004)\end{array}$ & & $\begin{array}{l}0.216^{* * *} \\
(0.030)\end{array}$ & $\begin{array}{l}0.214^{* * *} \\
(0.029)\end{array}$ & $\begin{array}{l}0.220^{* * * *} \\
(0.028)\end{array}$ \\
\hline firm_costobst & & $\begin{array}{c}0.098 \\
(0.079)\end{array}$ & $\begin{array}{c}0.100 \\
(0.081)\end{array}$ & $\begin{array}{c}0.103 \\
(0.081)\end{array}$ & & $\begin{array}{c}-0.118 \\
(0.657)\end{array}$ & $\begin{array}{l}-0.113 \\
(0.656)\end{array}$ & $\begin{array}{l}-0.032 \\
(0.646)\end{array}$ \\
\hline firm_infobst & & $\begin{array}{l}-0.096 \\
(0.132)\end{array}$ & $\begin{array}{l}-0.110 \\
(0.128)\end{array}$ & $\begin{array}{c}-0.111 \\
(0.126)\end{array}$ & & $\begin{array}{l}-0.355 \\
(0.665)\end{array}$ & $\begin{array}{c}-0.364 \\
(0.649)\end{array}$ & $\begin{array}{l}-0.421 \\
(0.640)\end{array}$ \\
\hline lfirm_age & & $\begin{array}{l}0.051^{* *} \\
(0.018)\end{array}$ & $\begin{array}{l}0.053^{* *} \\
(0.017)\end{array}$ & $\begin{array}{l}0.055^{* *} \\
(0.018)\end{array}$ & & $\begin{array}{c}0.017 \\
(0.125)\end{array}$ & $\begin{array}{c}0.026 \\
(0.123)\end{array}$ & $\begin{array}{c}0.058 \\
(0.128)\end{array}$ \\
\hline lgdp_prov & & $\begin{array}{c}-0.212^{* *} \\
(0.065)\end{array}$ & $\begin{array}{c}-0.276^{* *} \\
(0.079)\end{array}$ & $\begin{array}{c}-0.316^{* * *} \\
(0.073)\end{array}$ & & $\begin{array}{c}-1.897^{* *} \\
(0.514)\end{array}$ & $\begin{array}{l}-2.026^{* * *} \\
(0.698)\end{array}$ & $\begin{array}{l}-2.356^{* * *} \\
(0.663)\end{array}$ \\
\hline park_age & & & $\begin{array}{c}-0.034 \\
(0.019)\end{array}$ & $\begin{array}{l}-0.046^{*} \\
(0.017)\end{array}$ & & & $\begin{array}{l}-0.034 \\
(0.152)\end{array}$ & $\begin{array}{c}0.002 \\
(0.138)\end{array}$ \\
\hline park_agesq & & & $\begin{array}{c}0.001 \\
(0.001)\end{array}$ & $\begin{array}{c}0.001 * \\
(0.001)\end{array}$ & & & $\begin{array}{c}0.001 \\
(0.006)\end{array}$ & $\begin{array}{c}0.000 \\
(0.005)\end{array}$ \\
\hline lpark_firms & & & $\begin{array}{l}-0.029 \\
(0.016)\end{array}$ & $\begin{array}{l}-0.029 \\
(0.022)\end{array}$ & & & $\begin{array}{l}-0.146 \\
(0.148)\end{array}$ & $\begin{array}{l}-0.282 \\
(0.191)\end{array}$ \\
\hline lpark_staff & & & & $\begin{array}{c}0.031 \\
(0.018)\end{array}$ & & & & $\begin{array}{c}-0.050 \\
(0.129)\end{array}$ \\
\hline park_services_i & & & & $\begin{array}{l}0.074^{* *} \\
(0.024)\end{array}$ & & & & $\begin{array}{c}0.637^{*} \\
(0.239)\end{array}$ \\
\hline park_services_c & & & & $\begin{array}{c}-0.048 \\
(0.056)\end{array}$ & & & & $\begin{array}{c}-0.297 \\
(0.531)\end{array}$ \\
\hline$N$ & 849 & 849 & 849 & 849 & 849 & 849 & 849 & 849 \\
\hline
\end{tabular}

Marginal effects; Standard errors in parentheses are clustered by park. Reference park type is Pure Technology Park. VIF test shows no multicollinearity problems.

${ }^{*} p<0.05,{ }^{* *} p<0.01,{ }^{* * *} p<0.001$

\subsubsection{An additional check for omitted variable bias}

Similar to the results for innovation outputs, these results could be biased if the specific orientation of the firms' innovation processes is not captured adequately by the covariates. The composition of the R\&D team and, more specifically, the percentage of PhDs in total R\&D 
employees have been shown to influence the relative weight of universities in partner portfolios (Barge-Gil and Conti, 2013). Table 12 includes this indicator, and assumes that firms with no $R \& D$ department are product rather than science oriented and accordingly, are assigned zero for percentage of PhDs. Table 13 presents the regression excluding these firms. The results are similar to those in Table 11. No difference is found across park types for likelihood of cooperation with universities, and there is a positive, non-significant effect of Pure Science Parks for external R\&D. Finally, as expected the percentage of $\mathrm{PhDs}$ in the $\mathrm{R} \& \mathrm{D}$ team has positive coefficients, although they are significant only for the results for external R\&D in Table 12. 
Table 12. Influence of park type on links with universities. (Includes Phd. Full Sample).

\begin{tabular}{|c|c|c|c|c|}
\hline & $\begin{array}{c}\text { (I) } \\
\text { coop_uni }\end{array}$ & $\begin{array}{c}\text { (II) } \\
\text { coop_uni }\end{array}$ & $\begin{array}{c}\text { (III) } \\
\text { R\&D }\end{array}$ & $\begin{array}{l}\text { (IV) } \\
\text { R\&D }\end{array}$ \\
\hline Pure_Science_Park & $\begin{array}{c}-0.031 \\
(0.059)\end{array}$ & $\begin{array}{c}-0.050 \\
(0.070)\end{array}$ & $\begin{array}{c}0.664 \\
(0.526)\end{array}$ & $\begin{array}{c}0.890 \\
(0.655)\end{array}$ \\
\hline Mixed_Park & $\begin{array}{c}0.040 \\
(0.039)\end{array}$ & $\begin{array}{c}0.016 \\
(0.037)\end{array}$ & $\begin{array}{c}0.042 \\
(0.506)\end{array}$ & $\begin{array}{c}-0.303 \\
(0.495)\end{array}$ \\
\hline Tech_Park_with_University & $\begin{array}{c}0.009 \\
(0.029)\end{array}$ & $\begin{array}{c}0.027 \\
(0.030)\end{array}$ & $\begin{array}{c}0.099 \\
(0.242)\end{array}$ & $\begin{array}{c}0.113 \\
(0.227)\end{array}$ \\
\hline lfirm_sales & $\begin{array}{c}-0.002 \\
(0.011)\end{array}$ & $\begin{array}{c}-0.002 \\
(0.011)\end{array}$ & $\begin{array}{c}-0.007 \\
(0.070)\end{array}$ & $\begin{array}{c}-0.013 \\
(0.069)\end{array}$ \\
\hline lfirm_sales_q & $\begin{array}{c}0.001 \\
(0.001)\end{array}$ & $\begin{array}{c}0.001 \\
(0.001)\end{array}$ & $\begin{array}{c}0.003 \\
(0.004)\end{array}$ & $\begin{array}{c}0.003 \\
(0.004)\end{array}$ \\
\hline firm_exports & $\begin{array}{c}0.035 \\
(0.149)\end{array}$ & $\begin{array}{c}0.037 \\
(0.147)\end{array}$ & $\begin{array}{c}1.541 \\
(1.077)\end{array}$ & $\begin{array}{c}1.468 \\
(1.076)\end{array}$ \\
\hline firm_industry_restact & $\begin{array}{l}-0.183^{*} \\
(0.075)\end{array}$ & $\begin{array}{l}-0.186^{*} \\
(0.074)\end{array}$ & $\begin{array}{l}-0.738 \\
(0.421)\end{array}$ & $\begin{array}{l}-0.667 \\
(0.417)\end{array}$ \\
\hline firm_industry_low & $\begin{array}{c}-0.181 \\
(0.092)\end{array}$ & $\begin{array}{l}-0.162 \\
(0.089)\end{array}$ & $\begin{array}{l}-0.493 \\
(0.504)\end{array}$ & $\begin{array}{l}-0.450 \\
(0.512)\end{array}$ \\
\hline firm_industry_mlow & $\begin{array}{l}-0.267^{*} \\
(0.106)\end{array}$ & $\begin{array}{l}-0.269^{*} \\
(0.105)\end{array}$ & $\begin{array}{l}-1.175^{*} \\
(0.462)\end{array}$ & $\begin{array}{l}-1.211^{*} \\
(0.488)\end{array}$ \\
\hline firm_industry_mhigh & $\begin{array}{c}-0.309^{* * *} \\
(0.056)\end{array}$ & $\begin{array}{c}-0.300^{* * * *} \\
(0.054)\end{array}$ & $\begin{array}{c}-1.319^{* *} \\
(0.386)\end{array}$ & $\begin{array}{c}-1.274^{* *} \\
(0.401)\end{array}$ \\
\hline firm_industry_kis & $\begin{array}{c}-0.058 \\
(0.057)\end{array}$ & $\begin{array}{c}-0.061 \\
(0.058)\end{array}$ & $\begin{array}{c}-0.603 \\
(0.386)\end{array}$ & $\begin{array}{c}-0.569 \\
(0.387)\end{array}$ \\
\hline firm_industry_nkis & $\begin{array}{c}-0.211^{* *} \\
(0.057)\end{array}$ & $\begin{array}{c}-0.204^{* *} \\
(0.058)\end{array}$ & $\begin{array}{c}-1.125^{* *} \\
(0.396)\end{array}$ & $\begin{array}{l}-1.034^{*} \\
(0.387)\end{array}$ \\
\hline firm_innov_effort & $\begin{array}{c}0.033^{* * *} \\
(0.006)\end{array}$ & $\begin{array}{c}0.035^{* * *} \\
(0.006)\end{array}$ & $\begin{array}{l}0.290^{* *} \\
(0.083)\end{array}$ & $\begin{array}{l}0.301^{* *} \\
(0.083)\end{array}$ \\
\hline PhDs & $\begin{array}{c}0.179 \\
(0.097)\end{array}$ & $\begin{array}{c}0.176 \\
(0.096)\end{array}$ & $\begin{array}{c}1.895^{*} \\
(0.888)\end{array}$ & $\begin{array}{c}1.980^{*} \\
(0.888)\end{array}$ \\
\hline int_R\&D & $\begin{array}{c}0.056 \\
(0.059)\end{array}$ & $\begin{array}{c}0.042 \\
(0.061)\end{array}$ & $\begin{array}{c}-1.008 \\
(0.566)\end{array}$ & $\begin{array}{l}-1.063 \\
(0.565)\end{array}$ \\
\hline firm_costobst & $\begin{array}{c}0.104 \\
(0.081)\end{array}$ & $\begin{array}{c}0.109 \\
(0.082)\end{array}$ & $\begin{array}{c}-0.052 \\
(0.653)\end{array}$ & $\begin{array}{c}0.044 \\
(0.640)\end{array}$ \\
\hline firm_infobst & $\begin{array}{l}-0.109 \\
(0.131)\end{array}$ & $\begin{array}{l}-0.112 \\
(0.128)\end{array}$ & $\begin{array}{c}-0.307 \\
(0.645)\end{array}$ & $\begin{array}{c}-0.377 \\
(0.633)\end{array}$ \\
\hline lfirm_age & $\begin{array}{l}0.051^{* *} \\
(0.016)\end{array}$ & $\begin{array}{l}0.054^{* *} \\
(0.017)\end{array}$ & $\begin{array}{c}0.069 \\
(0.128)\end{array}$ & $\begin{array}{c}0.108 \\
(0.134)\end{array}$ \\
\hline lgdp_prov & $\begin{array}{c}-0.272^{* * *} \\
(0.080)\end{array}$ & $\begin{array}{c}-0.315^{\text {**** }} \\
(0.074)\end{array}$ & $\begin{array}{l}-2.143^{*} \\
(0.803)\end{array}$ & $\begin{array}{c}-2.509^{* *} \\
(0.713)\end{array}$ \\
\hline park_age & $\begin{array}{c}-0.034 \\
(0.019)\end{array}$ & $\begin{array}{l}-0.045^{*} \\
(0.016)\end{array}$ & $\begin{array}{c}-0.047 \\
(0.170)\end{array}$ & $\begin{array}{c}-0.001 \\
(0.147)\end{array}$ \\
\hline park_agesq & $\begin{array}{c}0.001 \\
(0.001)\end{array}$ & $\begin{array}{c}0.001^{*} \\
(0.001)\end{array}$ & $\begin{array}{c}0.001 \\
(0.006)\end{array}$ & $\begin{array}{c}0.000 \\
(0.005)\end{array}$ \\
\hline lpark_firms & $\begin{array}{c}-0.030 \\
(0.016)\end{array}$ & $\begin{array}{c}-0.033 \\
(0.022)\end{array}$ & $\begin{array}{l}-0.149 \\
(0.159)\end{array}$ & $\begin{array}{c}-0.313 \\
(0.207)\end{array}$ \\
\hline lpark_staff & & $\begin{array}{c}0.027 \\
(0.019)\end{array}$ & & $\begin{array}{c}-0.075 \\
(0.141)\end{array}$ \\
\hline park_services_i & & $\begin{array}{l}0.077^{* *} \\
(0.022)\end{array}$ & & $\begin{array}{l}0.701^{* *} \\
(0.247)\end{array}$ \\
\hline park_services_c & & $\begin{array}{c}-0.057 \\
(0.055)\end{array}$ & & $\begin{array}{c}-0.369 \\
(0.556) \\
\end{array}$ \\
\hline$N$ & 849 & 849 & 849 & 849 \\
\hline
\end{tabular}

Marginal effects; Standard errors in parentheses are clustered by park. Reference park type is Pure Technology Park. VIF test shows no multicollinearity problems.

${ }^{*} p<0.05,{ }^{* *} p<0.01,{ }^{* * *} p<0.001$ 
Table 13. Influence of park type on links with universities. (Includes Phd. Restricted Sample).

\begin{tabular}{|c|c|c|c|c|}
\hline & $\begin{array}{c}\text { (I) } \\
\text { coop_uni }\end{array}$ & $\begin{array}{c}\text { (II) } \\
\text { coop_uni }\end{array}$ & $\begin{array}{l}\text { (III) } \\
\text { R\&D }\end{array}$ & $\begin{array}{l}\text { (IV) } \\
\text { R\&D }\end{array}$ \\
\hline Pure_Science_Park & $\begin{array}{l}-0.038 \\
(0.069)\end{array}$ & $\begin{array}{l}-0.034 \\
(0.084)\end{array}$ & $\begin{array}{c}0.541 \\
(0.570)\end{array}$ & $\begin{array}{c}0.951 \\
(0.692)\end{array}$ \\
\hline Mixed_Park & $\begin{array}{c}0.025 \\
(0.054)\end{array}$ & $\begin{array}{l}-0.013 \\
(0.048)\end{array}$ & $\begin{array}{l}-0.046 \\
(0.692)\end{array}$ & $\begin{array}{l}-0.515 \\
(0.640)\end{array}$ \\
\hline Tech_Park_with_University & $\begin{array}{c}0.004 \\
(0.043)\end{array}$ & $\begin{array}{c}0.025 \\
(0.037)\end{array}$ & $\begin{array}{c}0.051 \\
(0.324)\end{array}$ & $\begin{array}{c}0.061 \\
(0.268)\end{array}$ \\
\hline lfirm_sales & $\begin{array}{l}-0.007 \\
(0.012)\end{array}$ & $\begin{array}{l}-0.008 \\
(0.013)\end{array}$ & $\begin{array}{l}-0.051 \\
(0.089)\end{array}$ & $\begin{array}{l}-0.059 \\
(0.089)\end{array}$ \\
\hline lfirm_sales_q & $\begin{array}{c}0.001 \\
(0.001)\end{array}$ & $\begin{array}{c}0.001 \\
(0.001)\end{array}$ & $\begin{array}{c}0.008 \\
(0.006)\end{array}$ & $\begin{array}{c}0.008 \\
(0.006)\end{array}$ \\
\hline firm_exports & $\begin{array}{l}-0.100 \\
(0.212)\end{array}$ & $\begin{array}{l}-0.106 \\
(0.211)\end{array}$ & $\begin{array}{c}1.844 \\
(1.192)\end{array}$ & $\begin{array}{c}1.669 \\
(1.227)\end{array}$ \\
\hline firm_industry_restact & $\begin{array}{l}-0.238^{*} \\
(0.105)\end{array}$ & $\begin{array}{l}-0.237^{*} \\
(0.104)\end{array}$ & $\begin{array}{l}-0.762 \\
(0.662)\end{array}$ & $\begin{array}{l}-0.682 \\
(0.671)\end{array}$ \\
\hline firm_industry_low & $\begin{array}{l}-0.083 \\
(0.164)\end{array}$ & $\begin{array}{l}-0.077 \\
(0.160)\end{array}$ & $\begin{array}{c}0.354 \\
(0.906)\end{array}$ & $\begin{array}{c}0.316 \\
(0.926)\end{array}$ \\
\hline firm_industry_mlow & $\begin{array}{l}-0.255 \\
(0.138)\end{array}$ & $\begin{array}{l}-0.264 \\
(0.138)\end{array}$ & $\begin{array}{l}-1.094 \\
(0.571)\end{array}$ & $\begin{array}{l}-1.200 \\
(0.602)\end{array}$ \\
\hline firm_industry_mhigh & $\begin{array}{c}-0.298^{* * *} \\
(0.075)\end{array}$ & $\begin{array}{c}-0.286^{* * * *} \\
(0.075)\end{array}$ & $\begin{array}{l}-1.222^{*} \\
(0.490)\end{array}$ & $\begin{array}{l}-1.158^{*} \\
(0.520)\end{array}$ \\
\hline firm_industry_kis & $\begin{array}{c}-0.044 \\
(0.078)\end{array}$ & $\begin{array}{c}-0.048 \\
(0.078)\end{array}$ & $\begin{array}{l}-0.559 \\
(0.463)\end{array}$ & $\begin{array}{l}-0.557 \\
(0.468)\end{array}$ \\
\hline firm_industry_nkis & $\begin{array}{l}-0.259^{*} \\
(0.095)\end{array}$ & $\begin{array}{l}-0.253^{*} \\
(0.094)\end{array}$ & $\begin{array}{l}-1.474^{*} \\
(0.530)\end{array}$ & $\begin{array}{l}-1.418^{*} \\
(0.531)\end{array}$ \\
\hline firm_innov_effort & $\begin{array}{c}0.071^{* * * *} \\
(0.011)\end{array}$ & $\begin{array}{c}0.074^{* * * *} \\
(0.011)\end{array}$ & $\begin{array}{l}0.565^{* *} \\
(0.159)\end{array}$ & $\begin{array}{l}0.588^{* *} \\
(0.160)\end{array}$ \\
\hline PhDs & $\begin{array}{c}0.154 \\
(0.093)\end{array}$ & $\begin{array}{c}0.154 \\
(0.093)\end{array}$ & $\begin{array}{c}1.627 \\
(0.887)\end{array}$ & $\begin{array}{c}1.752 \\
(0.896)\end{array}$ \\
\hline firm_costobst & $\begin{array}{c}0.132 \\
(0.096)\end{array}$ & $\begin{array}{c}0.140 \\
(0.096)\end{array}$ & $\begin{array}{l}-0.039 \\
(0.867)\end{array}$ & $\begin{array}{c}0.032 \\
(0.852)\end{array}$ \\
\hline firm_infobst & $\begin{array}{l}-0.140 \\
(0.182)\end{array}$ & $\begin{array}{l}-0.146 \\
(0.178)\end{array}$ & $\begin{array}{l}-0.265 \\
(0.835)\end{array}$ & $\begin{array}{l}-0.350 \\
(0.818)\end{array}$ \\
\hline lfirm_age & $\begin{array}{l}0.068^{* *} \\
(0.021)\end{array}$ & $\begin{array}{l}0.072^{* *} \\
(0.021)\end{array}$ & $\begin{array}{c}0.021 \\
(0.175)\end{array}$ & $\begin{array}{c}0.054 \\
(0.180)\end{array}$ \\
\hline lgdp_prov & $\begin{array}{c}-0.399^{* * * *} \\
(0.093)\end{array}$ & $\begin{array}{c}-0.459^{* * * *} \\
(0.096)\end{array}$ & $\begin{array}{l}-2.921^{* * *} \\
(1.028)\end{array}$ & $\begin{array}{c}-3.481^{* * * *} \\
(0.862)\end{array}$ \\
\hline park_age & $\begin{array}{l}-0.045^{*} \\
(0.020)\end{array}$ & $\begin{array}{l}-0.049^{*} \\
(0.020)\end{array}$ & $\begin{array}{l}-0.118 \\
(0.210)\end{array}$ & $\begin{array}{l}-0.018 \\
(0.176)\end{array}$ \\
\hline park_agesq & $\begin{array}{c}0.001^{*} \\
(0.001)\end{array}$ & $\begin{array}{l}0.002^{*} \\
(0.001)\end{array}$ & $\begin{array}{c}0.003 \\
(0.008)\end{array}$ & $\begin{array}{c}0.001 \\
(0.006)\end{array}$ \\
\hline lpark_firms & $\begin{array}{l}-0.039 \\
(0.025)\end{array}$ & $\begin{array}{l}-0.051 \\
(0.033)\end{array}$ & $\begin{array}{l}-0.171 \\
(0.206)\end{array}$ & $\begin{array}{l}-0.441 \\
(0.263)\end{array}$ \\
\hline lpark_staff & & $\begin{array}{c}0.021 \\
(0.027)\end{array}$ & & $\begin{array}{l}-0.170 \\
(0.195)\end{array}$ \\
\hline park_services_i & & $\begin{array}{c}0.115^{* * * *} \\
(0.026)\end{array}$ & & $\begin{array}{l}0.947^{* *} \\
(0.310)\end{array}$ \\
\hline park_services_c & & $\begin{array}{c}-0.074 \\
(0.064)\end{array}$ & & $\begin{array}{l}-0.497 \\
(0.634)\end{array}$ \\
\hline$N$ & 667 & 667 & 667 & 667 \\
\hline
\end{tabular}

Marginal effects; Standard errors in parentheses are clustered by park. Reference park type is Pure Technology Park. VIF test shows no multicollinearity problems.

${ }^{*} p<0.05,{ }^{* *} p<0.01,{ }^{* * * *} p<0.001$ 


\section{Discussion and conclusions}

STPs are the subject of debate over their effectiveness for supporting business innovativeness and encouraging the establishment of links between firms and universities. However, the extent to which the degree of involvement of universities in parks influences park firms' innovation outcomes and links with universities has not been addressed so far.

We investigate this by studying how different degrees of involvement of a university in an STP are related to firms' innovation outputs measured as sales of new to the market products and numbers of patent applications, and links between STP firms and universities measured as cooperation and purchase of university R\&D services. To this end we have distinguished four types of park: Pure Science Parks, where the university is the major shareholder; Mixed Parks, in which a university is a minority shareholder; Technology Parks with University, where there is no university shareholding, but some university research facilities are located in the park; and Pure Technology Parks, in which the university has no formal involvement.

We exploit firm level data from the Spanish CIS and we match them with park-level data from the Survey 2009 on the Characteristics and Results of Science and Technology Parks.

Our results for innovation output show clear specialization according to park type: Pure Science Park firms show highest patenting performance and lowest product innovation levels, while Pure Technology Park firms perform best for sales of new to the market products and worst for patenting.

There are several plausible explanations for this result. The first one points to the existence of different types of knowledge in different types of parks. We may expect that the knowledge transferred is more scientific and analytical, and thus more suitable to be codified in patents (Brusoni et al., 2005; Asheim and Coenen, 2005) when the involvement of universities within the park is higher.. An alternative, complementary explanation is that patenting could be a way to solve conflicts between universities and industry (Hall et al., 2001), characterised by a very different economic logic (Foray and Lissoni, 2010). Nonetheless the higher patenting activity is not translated into higher product innovation. Spanish universities have traditionally encountered problems to transform knowledge into new products (Albert and Plaza, 2004; Testar Ymbert, 2012) and it would seem that parks with a higher university presence (Pure Science Parks and Mixed Parks) have the same problem. Additionally, different types of parks may have different mission and objectives. The need to consider the actual mission and major stakeholders commitment has been underlined in the literature (Bigliardi et al., 2006). If universities are interested in developing Science Parks to facilitate commercialization of 
academic research and to internalize financial returns of academic research (Storey and Tether, 1998b; Link et al., 2007), our results show that a greater effort is needed to accomplish this aim.

Another reason may be related with the recent change in Spanish universities' reward system for academics. Spain has registered in recent years a spectacular increase in the number of scientific publications and it is presently one of the countries with higher production of scientific knowledge (Albert and Plaza, 2004). This increase is most likely due to the reward and access system to university positions in Spain, which incentivizes publication in internationally recognized scientific journals. The same reward system has recently included the number of patents obtained by professors and researchers for curriculum evaluations purposes (TorresAlbero et al., 2010). Thus academics are encouraged to obtain patents, regardless of their commercial application potential.

For cooperation with a university and the amount of R\&D services bought from a university, we find no robust evidence of an influence of the type of the park, once firms' characteristics are controlled for. No effect is found regarding likelihood of cooperation with universities and a positive non significant effect is found for Pure Science Parks when analyzing external R\&D. If one of the reasons why universities develop Science Parks is to encourage more cooperation between firms and universities, then the Spanish experience would seem to indicate that the purpose of this effort is not being accomplished so far. Firms in Pure Science Parks do not show higher likelihood of cooperation with universities than firms located in other types of parks, and the higher external $R \& D$ with universities is not statistically significant. This finding is in line with what D'Este et al. (2013) find in their study on the formation of university-industry research collaboration. They show that geographical clustering of technologically complementary firms - such as those in STPs, regardless their type - makes the geographical proximity of industry and university partners far less important for the establishment of collaboration. Furthermore, it has been found that, while patenting activity of universities has greatly increased recently (Bruneel et al., 2010), the collaboration university-industry seems to slow down (Valentin and Jensen, 2007), probably due to the conflicts generated by the increased interest of universities in obtaining and exploiting formal IP (Bruneel et al., 2010).

It could be argued that above results might be biased by the different orientation of the firms' innovation processes - more or less scientific oriented - in different types of parks, and by other park characteristics. We have deployed several strategies to be confident that this is not the case. We applied a hierarchical regression approach controlling progressively by a large set of firm level covariates and by different park characteristics. In addition, we performed an additional check for the existence of an omitted variable bias that confirmed previous results. 
Our research has implications at different levels. On a theoretical level, we contribute to the literature on STPs introducing a taxonomy of STPs based on the level of university involvement. Previous attempts to differentiate between different types of parks has either been unsuccessful ${ }^{27}$ or based on a too fuzzy definition of the different types of parks. ${ }^{28}$

On a managerial level, for university managers our study indicates that university involvement in park ownership/management allows firms to benefit from the knowledge created in the university, but that more effort is needed to transform this knowledge into commercial outputs. University managers should also be aware that firms on parks managed by universities do not cooperate more with universities than those located in other types of parks. For firms' managers deciding about on-park or off-park location, this research suggests that they need to be aware that different types of parks (more scientific versus more technology oriented) have different effects on tenant firms' innovation.

Finally, for policy-makers our research suggests that different type of parks have different effects on the innovation performance of tenants. Accordingly, a 'one size fits all' approach is not adequate. Depending on the relative weaknesses and strengths of the specific location, a specific type of park would be more convenient.

We have found a relation between the level of involvement of universities within parks and firms' innovative outputs, and we have provided possible explanations for these results. Future research may be focused on testing whether these different explanations hold. Although it would require large amounts of data, it would be interesting for future research to analyse the relationship between firms' characteristics and type of STP. It would also be informative to replicate this study in other countries, such as the US, where universities tend to be more entrepreneurial than in Spain. Future research could also assess how the quality of the academic research affects park tenants' innovation. Finally, other less formal indicators of technology transfer between universities and park firms could be employed.

\footnotetext{
${ }^{27}$ E.g. the one introduced by the European Union (Scandizzo, 2005).

${ }^{28}$ E.g. Minguillo and Thelwall (2015) base their study on the self-denomination of parks and the definitions of different park types, such as Research Park, Science Park, Science and Innovation Park, etc. are often very overlapping.
} 


\section{References}

ALBAHARI, A., BARGE-GIL, A., PÉREZ-CANTO, S. and MODREGO, A. (2016): "The influence of Science and Technology Parks' characteristics on firms' innovation results". Papers in Regional Science. In press.[DOI: 10.1111/pirs.12253].

ALBAHARI, A., CATALANO, G. and LANDONI, P. (2013): "Evaluation of national Science Park Systems: a theoretical framework and its application to the Italian and Spanish systems". Technology Analysis and Strategic Management, 25, 5, 599-614.

ALBERT, A. and PLAZA, L. M. (2004): "The transfer of knowledge from the Spanish public R\&D system to the productive sectors in the field of Biotechnology". Scientometrics, 59, 1, 314.

ANGRIST, J. and PISCHKE, J.S. (2009): Mostly Harmless Econometrics: An Empiricist's Companion. Princeton University Press.

APTE (2015): Memoria APTE 2014. Malaga: APTE, Association of Science and Technology Parks of Spain.

ASHEIM, B. T. and COENEN, L. (2005): "Knowledge bases and regional innovation systems: Comparing Nordic clusters". Research policy, 34, 8, 1173-1190.

AUDRETSCH, D.B. and FELDMAN, M.P. (1996): "R\&D spillovers and the geography of innovation and production". The American Economic Review, 86, 3, 630-640.

BARGE-GIL, A. (2013): "Open strategies and innovation performance". Industry and Innovation, 20, 7, 585-610.

BARGE-GIL, A. and CONTI, A. (2013): "An analysis of the determinants of outsourcing by Spanish R\&D firms". MPRA Paper 44090, University Library of Munich, Germany.

BARGE-GIL, A., and LÓPEZ, A. (2015): "R versus D: Estimating the differentiated effect of research and development on innovation results". Industrial and Corporate Change, 24, 1, 93129.

BARGE-GIL, A., NIETO, M.J. and SANTAMARÍA, L. (2011a): "Hidden innovators: the role of non-R\&D activities". Technology Analysis and Strategic Management, 23, 4, 415-432.

BARGE-GIL, A., SANTAMARÍA, L. and MODREGO, A. (2011b): "Complementarities between universities and technology institutes. New empirical lessons and perspectives". European Planning Studies, 19, 2, 195-215.

BERCOVITZ, J. and FELDMANN, M. (2006): "Entrepreneurial universities and technology transfer: A conceptual framework for understanding knowledge-based economic development". The Journal of Technology Transfer, 31,1, 175-188.

BIGLIARDI, B., DORMIO, A. I., NOSELLA, A. and PETRONI, G. (2006): “Assessing science parks' performances: directions from selected Italian case studies”. Technovation, 26, 4, 489505.

BOSCHMA, R. (2005): "Proximity and innovation: a critical assessment". Regional Studies, 39, 1, 61-74.

BOZEMAN, B. (2000): "Technology transfer and public policy: a review of research and theory". Research Policy, 29, 4, 627-655.

BRESCHI, S. and LISSONI, F. (2001): "Knowledge spillovers and local innovation systems: a critical survey". Industrial and Corporate Change, 10, 4, 975-1005.

BRUNEEL, J., D'ESTE, P. and SALTER, A. (2010): "Investigating the factors that diminish the barriers to university-industry collaboration". Research Policy, 39, 7, 858-868. 
BRUSONI, S., MARSILI, O. and SALTER, A. (2005): "The role of codified sources of knowledge in innovation: Empirical evidence from Dutch manufacturing". Journal of Evolutionary Economics, 15, 2, 211-231.

CALDERA, A. and DEBANDE, O. (2010): "Performance of Spanish universities in technology transfer: An empirical analysis". Research Policy, 39, 9, 1160-1173.

CHAN, K.Y. A., OERLEMANS, L.A. and PRETORIUS, M.W. (2011): "Innovation outcomes of South African new technology-based firms: a contribution to the debate on the performance of science park firms". South African Journal of Economic and Management Sciences, 14, 4, 361-378.

CHESBROUGH, H.W. (2003): Open Innovation. The New Imperative for Creating and Profiting from Technology. Boston: Harvard Business School Press.

CHORDA, I.M. (1996): "Towards the maturity stage: An insight into the performance of French technopoles". Technovation, 16, 3, 143-152.

COHEN, W.M., NELSON, R.R. and WALSH, J.P. (2002): "Links and impacts: the influence of public research on industrial R\&D". Management Science, 48, 1, 1-23.

COLOMBO, M.G. and DELMASTRO, M. (2002): "How effective are technology incubators? Evidence from Italy". Research Policy, 31, 7, 1103-1122.

COTEC (2011): Análisis de la evolución de los parques científicos españoles. Madrid: Fundación Cotec para la Innovación Tecnológica.

CZARNITZKI, D. and HOTTENROTT, H. (2009): "Are local milieus the key to innovation performance?". Journal of Regional Science, 49, 1, 81-112.

CZARNITZKI, D., EBERSBERGER, B. and FIER, A. (2007): “The relationship between R\&D collaboration, subsidies and R\&D performance: empirical evidence from Finland and Germany". Journal of applied econometrics, 22, 7, 1347-1366.

CZARNITZKI, D., KRAFT, K. and THORWARTH, S. (2009): "The knowledge production of 'R'and 'D'”. Economics Letters, 105,1, 141-143.

DEL CASTILlO HERMOSA, J. and BARROETA, B. (1998): "The technology park at Beocillo: an instrument for regional development in Castilla-Leon". Progress in Planning, 49, 3-4, 241-254.

D'ESTE, P., GUY, F. and IAMMARINO, S. (2013): "Shaping the formation of universityindustry research collaborations: what type of proximity does really matter?". Journal of Economic Geography, 13, 537-558.

DÍEZ-VIAL, I. and FERNÁNDEZ-OLMOS, M. (2015): "Knowledge spillovers in science and technology parks: how can firms benefit most?". The Journal of Technology Transfer, 40, 1, 7084.

DIÉZ-VIAL, I. and FERNÁNDEZ-OLMOS, M. (2016): "The effect of science and technology parks on a firm's performance: a dynamic approach over time". Journal of Evolutionary Economics, DOI: 10.1007/s00191-016-0481-5. In press.

ETZKOWITZ, H. and L. LEYDESDORFF (1997): Universities and the Global Knowledge Economy: A Triple Helix of University-Industry-Government Relations. Pinter, London.

FAEMS, D., VAN LOOY, B. and DEBACKERE, K. (2005): "Interorganizational collaboration and innovation: toward a portfolio approach". The Journal of Product Innovation Management $22,3,238-250$. 
FELSENSTEIN, D. (1994): "University-related Science Parks - Seedbeds or enclaves of innovation". Technovation, 14, 2, 93-110.

FISCHER, M.M. and VARGA, A. (2003): "Spatial knowledge spillovers and university research: evidence from Austria". The Annals of Regional Science, 37, 2, 303-322.

FORAY, D. and LISSONI, F. (2010): University research and public-private interaction. In Hall, B.H. and Rosenberg, N. (eds.), Handbook of the Economics of Innovation, Volume I. Elsevier, Amsterdam, 276-314.

FRANSMAN, M. (2008): "Disaggregating Firms In Analysing The Costs And Benefits Of The University-Industry Relationship: Based On An Analytical And Empirical Study From Scotland." Economics of Innovation and New Technology, 17, 1-2, 123-136.

FRENZ, M. and IETTO-GILLIES, G. (2009): "The impact on innovation performance of different sources of knowledge: evidence from the UK Community Innovation Survey". Research Policy, 38, 7, 1125-1135.

FUKUGAWA, N. (2006): "Science parks in Japan and their value-added contributions to new technology-based firms". International Journal of Industrial Organization, 24, 2, 381-400.

GARCIA-PEREZ-DE-LEMA, D., MADRID-GUIJARRO, A. and MARTIN, D.P. (2016): "Influence of university-firm governance on SMEs innovation and performance levels". Technological Forecasting and Social Change. DOI: 10.1016/j.techfore.2016.04.003. In press.

GERTLER, M. S. (2003): "Tacit knowledge and the economic geography of context, or the undefinable tacitness of being (there)". Journal of economic geography, 3, 1, 75-99.

GLAESER, E. L., KALLAL, H., SCHEINKMAN, J., and SCHLEIFER, A. (1992): "Cities and growth". The Journal of Political Economy, 100, 6, 1126-1152.

GRILICHES, Z. (1998): Patent statistics as economic indicators: a survey. In Griliches, Z. (ed.), $R \& D$ and productivity: the econometric evidence. University of Chicago Press, Chicago, 287343.

GULBRANDSEN, M. and SLIPERSÆTER, S. (2007): The third mission and the entrepreneurial university model. In: Bonaccorsi, A. and Daraio, C. (eds.), Universities and strategic knowledge creation. Specialization and Performance in Europe. Edward Elgar, Cheltenham, 112-143.

HALL, B. H., LINK, A. N. and SCOTT, J. T. (2001): "Barriers inhibiting industry from partnering with universities: evidence from the advanced technology program". The Journal of Technology Transfer, 26, 1-2, 87-98.

HANSSON, F., HUSTED, K. and VESTERGAARD, J. (2005): "Second generation science parks: from structural holes jockeys to social capital catalysts of the knowledge society". Technovation, 25, 9, 1039-1049.

HERRERA, L. and NIETO, M. (2015): "PhD careers in Spanish industry: Job determinants in manufacturing versus non-manufacturing firms". Technological Forecasting and Social Change. DOI::10.1016/j.techfore.2015.09.019. In press.

HERVAS-OLIVER, J. L. and ALBORS-GARRIGOS, J. (2009): "The Role of the Firm's Internal and Relational Capabilities in Clusters: When Distance and Embeddedness are not Enough to Explain Innovation". Journal of Economic Geography, 9, 2, 263-283.

HEYDEBRECK, P., KLOFSTEN, M. and MAIER, J. (2000): "Innovation support for new technology-based firms: the Swedish Teknopol approach". R\&D Management, 30, 1, 89-100.

HOMMEN, L., DOLOREUX, D. and LARSSON, E. (2006): "Emergence and growth of Mjardevi Science Park in Linkoping, Sweden”. European Planning Studies, 14, 10, 1331-1361. 
HOWELLS, J.R.L. (2002): "Tacit knowledge, innovation and economic geography". Urban Studies, 39, 5-6, 871-884.

HUANG, K.F., YU, C.M.J. and SEETOO, D.H. (2012): "Firm innovation in policy-driven parks and spontaneous clusters: the smaller firm the better?". The Journal of Technology Transfer, 37, 5, 715-731.

IASP (2002): IASP International Board, 6 February 2002. IASP, Malaga.

JAFFE, A.B., TRAJTENBERG, M. and HENDERSON, R. (1993): "Geographic Localization of Knowledge Spillovers as Evidenced by Patent Citations". The Quarterly Journal of Economics, 108, 3, 577-598.

JONGBLOED, B., ENDERS, J. and SALERNO, C. (2008): "Higher education and its communities: Interconnections, interdependencies and a research agenda". Higher education, 56, 3, 303-324.

KNOBEN, J. and OERLEMANS, L.A.G. (2006): "Proximity and inter-organizational collaboration: a literature review". International Journal of Management Reviews, 8, 2, 71-89.

LAWTON SMITH, H. (2007): "Universities, innovation, and territorial development: a review of the evidence". Environment and Planning C: Government and Policy, 25, 1, 98-114.

LIBERATI, D., MARINUCCI, M. and TANZI, G.M. (2016): "Science and Technology Parks in Italy: main features and analysis of their effects on the firms hosted". The Journal of Technology Transfer, 41, 4, 694-729.

LINK, A.N. and SCOTT, J.T. (2005): "Opening the ivory tower's door: An analysis of the determinants of the formation of US university spin-off companies". Research Policy, 34, 7, 1106-1112.

LINK, A.N. and SCOTT, J.T. (2007): "The economics of university research parks". Oxford Review of Economic Policy, 23, 4, 661-674.

LINK, A.N., SIEGEL, D.S. and BOZEMAN, B. (2007): "An empirical analysis of the propensity of academics to engage in informal university technology transfer". Industrial and Corporate Change, 16, 4, 641-655.

LÖFSTEN, H. and LINDELÖF, P. (2002): "Science Parks and the growth of new technologybased firms - academic-industry links, innovation and markets". Research Policy, 31, 6, 859876.

MACDONALD, S. (1987): "British Science Parks: reflections on the politics of high technology". R\&D Management, 17, 1, 25-37.

MALAIRAJA, C. and ZAWDIE, G. (2008): "Science parks and university-industry collaboration in Malaysia". Technology Analysis \& Strategic Management, 20, 6, 727-739.

MANSFIELD, E. and LEE, J.Y. (1996): "The modern university: contributor to industrial innovation and recipient of industrial R\&D support". Research policy, 25, 7, 1047-1058.

MASSEY, D., QUINTAS, P. and WIELD, D. (1992): High Tech Fantasies: Science Parks in Society, Science and Space. Routledge, London.

MAURSETH, P.B. and VERSPAGEN, B. (2002): "Knowledge spillovers in Europe: a patent citations analysis". The Scandinavian journal of economics, 104, 4, 531-545.

MCCANN, B.T. and FOLTA, T.B. (2008): "Location matters: where we have been and where we might go in agglomeration research". Journal of management, 34, 3, 532-565. 
MINGUILLO, D. and THELWALL, M. (2015): "Which are the best innovation support infrastructures for universities? Evidence from R\&D output and commercial activities". Scientometrics, 102, 1, 1057-1081.

MINGUILLO, D., TIJSSEN, R. and THELWALL, M. (2015): "Do science parks promote research and technology? A scientometric analysis of the UK". Scientometrics, 102, 1, 701-725.

MONCK, C.S.P., PORTER, R.B., QUINTAS, P., STOREY, D. and WYNARCZYK P. (1988): Science Parks and the Growth of High-Technology Firms. Croom Helm, London.

MONTORO-SÁNCHEZ, A., ORTIZ-DE-URBINA-CRIADO, M. and MORA-VALENTÍN, E.V. (2011): "Effects of knowledge spillovers on innovation and collaboration in science and technology parks", Journal of Knowledge Management, 15, 6, 948-970.

MUSCIO, A. and POZZALI, A. (2013): "The effects of cultural distance in university-industry collaborations. Some evidence from Italian universities". Journal of Technology Transfer, 38, 4, 486-508.

OERLEMANS, L. and MEEUS, M. (2005): "Do organizational and spatial proximity impact on firm performance?”. Regional studies, 39, 1, 89-104.

PERKMANN, M. and WALSH, K. (2007): "University-industry relationships and open innovation: Towards a research agenda". International Journal of Management Reviews, 9, 4, 259-280.

PERKMANN, M., TARTARI, V., MCKELVEY, M., AUTIO, E., BROSTRÖM, A., D'ESTE, P., FINI, R., GEUNA, A., GRIMALDI, R., HUGHES, A., KRABEL, S., KITSON, M., LLERENA, P., LISSONI, F., SALTER, A. and SOBRERO, M. (2013): "Academic engagement and commercialisation: A review of the literature on university-industry relations". Research Policy, 42, 2, 423-442.

PHAN P.H., SIEGEL D.S. and WRIGHT M. (2005): "Science parks and incubators: observations, synthesis and future research". Journal of Business Venturing, 20, 2, 165-182.

PHILLIMORE, J. (1999): "Beyond the linear view of innovation in science park evaluation An analysis of Western Australian Technology Park". Technovation, 19, 11, 673-680.

PHILLIPS, S. A. M. and YEUNG, H. W. C. (2003): "A place for R\&D? The Singapore Science Park". Urban Studies, 40, 4, 707-732.

PREVEZER, M. (1997): “The dynamics of industrial clustering in biotechnology". Small Business Economics, 9, 3, 255-271.

QUINTAS, P., WIELD D. and MASSEY, D. (1992): “Academic-industry links and innovation - Questioning the science park model". Technovation, 12, 3, 161-175.

RATINHO, T. and HENRIQUES, E. (2010): "The role of science parks and business incubators in converging countries: Evidence from Portugal". Technovation, 30, 4, 278-290.

SALTER, A.J. and MARTIN, B.R. (2001): "The economic benefits of publicly funded basic research: a critical review". Research Policy, 30, 3, 509-532.

SCANDIZZO, P. L. (2005): "Financing technology: an assessment of theory and practice". International Journal of Technology Management, 32, 1, 1-33.

SIEGEL, D.S., WESTHEAD, P. and WRIGHT, M. (2003a): "Science parks and the performance of new technology-based firms: a review of recent UK evidence and an agenda for future research". Small Business Economics, 20, 2, 177-184.

SIEGEL, D.S., WESTHEAD, P. and WRIGHT, M. (2003b): "Assessing the impact of university science parks on research productivity: exploratory firm-level evidence from the United Kingdom”. International Journal of Industrial Organization, 21, 9, 1357-1369. 
SONN, J.W. and STORPER, M. (2008): "The increasing importance of geographical proximity in knowledge production: an analysis of US patent citations, 1975-1997". Environment and Planning A, 40, 5, 1020-1039.

SQUICCIARINI, M. (2008): "Science Parks' tenants versus out-of-Park firms: who innovates more? A duration model". Journal of Technology Transfer, 33, 1, 45-71.

SQUICCIARINI, M. (2009): "Science parks: seedbeds of innovation? A duration analysis of firms' patenting activity". Small Business Economics, 32, 2, 169-190.

STOREY, D.J. and TETHER B.S. (1998a): "New technology-based firms in the European Union: an introduction". Research Policy, 26, 9, 933-946.

STOREY, D.J. and TETHER, B.S. (1998b): "Public policy measures to support new technology-based firms in the European Union". Research Policy, 26, 9, 1037-1057.

TESTAR YMBERT, X. (2012): Informe CYD 2011. Monografía. La transferencia de tecnología y conocimiento universidad-empresa en España: estado actual, retos y oportunidades. Eds. Fundación Conocimiento y Desarrollo, Barcelona.

TORRES-ALBERO, C., FERNÁNDEZ-ESQUINAS, M., REY-ROCHA, J. and MARTINSEMPERE, M. J. (2010): "Dissemination practices in the Spanish research system: scientists trapped in a golden cage". Public Understanding of Science, 20, 1, 1-14.

TSAI, K. (2009): "Collaborative networks and product innovation performance: toward a contingency perspective". Research Policy, 38, 7, 765-778.

VALENTIN, F. and JENSEN, R.L. (2007): "Effects on academia-industry collaboration of extending university property rights". Journal of Technology Transfer, 32, 3, 251-276.

VÁSQUEZ-URRIAGO, A. R., BARGE-GIL, A. and MODREGO, A. (2016a): "Which firms benefit more from being located in a Science and Technology Park? Empirical evidence for Spain”. Research Evaluation, 25, 1, 107-117.

VÁSQUEZ-URRIAGO, A.R., BARGE-GIL, A. and MODREGO, A. (2016b): "Science and Technology Parks and cooperation for innovation: Empirical evidence from Spain". Research Policy, 45, 1, 137-147.

VÁSQUEZ-URRIAGO, A.R., BARGE-GIL, A., MODREGO, A. and PARASKEVOPOULOU, E. (2014): "The impact of science and technology parks on firms' product innovation: empirical evidence from Spain". Journal of Evolutionary Economics, 24, 4, 835-873.

VEDOVELLO, C. (1997): "Science parks and university-industry interaction: geographical proximity between the agents as a driving force". Technovation, 17, 9, 491-502.

VEUGELERS, R. and CASSIMAN, B. (2005): "R\&D cooperation between firms and universities. Some empirical evidence from Belgian manufacturing". International Journal of Industrial Organization, 23, 5, 355-379.

WAINOVA (2009): Wainova Atlas of Innovation: Science/Technology/Research Parks and business incubators in the world. Ten Alps Publishing, Cheshire.

WESTHEAD, P. (1997): 'R\&D 'inputs' and 'outputs' of technology-based firms located on and off science parks". $R \& D$ Management, 27, 1, 45-62.

WESTHEAD, P. and BATSTONE, S. (1998): "Independent technology-based firms: The perceived benefits of a science park location”. Urban Studies, 35, 12, 2197-2219.

WESTHEAD, P. and STOREY, D.J. (1995): "Links between higher-education institutions and high-technology firms". Omega, 23, 4, 345-360. 
WRIGHT, M., LIU, X. H., BUCK, T. and FILATOTCHEV, I. (2008): "Returnee entrepreneurs, science park location choice and performance: An analysis of high-technology SMEs in China". Entrepreneurship Theory and Practice, 32, 1, 131-155.

YANG, C. H., MOTOHASHI, K. and CHEN, J.R. (2009): "Are new technology-based firms located on science parks really more innovative? Evidence from Taiwan". Research Policy, 38, $1,77-85$. 


\section{Annexes}

Table A1. Descriptive statistics for Pure Science Parks (112 observations)

\begin{tabular}{lllll}
\hline Variable & Mean & Std. Dev. & Min & Max \\
\hline Dependent Variables & & & & \\
\hline new_prod & 7802.071 & 16807.96 & 0 & 104470.1 \\
patnuml & 1309.76 & 3438.015 & 0 & 26000 \\
coop_uni & .3839286 & .4885267 & 0 & 1 \\
RDboughtl & 1619.849 & 4763.997 & 0 & 34352.5 \\
\hline Independent variables - STPs' characteristics & & \\
\hline park_age & 8.973214 & 1.890993 & 7 & 12 \\
park_firms & 150.2946 & 70.99697 & 2 & 209 \\
park_staff & 93.11475 & 168.3715 & 15 & 1550 \\
park_services_i & .8660714 & .3421062 & 0 & 1 \\
park_services_c & .8660714 & .3421062 & 0 & 1 \\
\hline Control variables -firms'characteristics & & \\
\hline firm_age & 9.107143 & 8.243323 & 1 & 39 \\
firm_sales & $2.03 \mathrm{e}+07$ & $1.12 \mathrm{e}+08$ & 0 & $1.02 \mathrm{e}+09$ \\
firm_exports & .0255383 & .0941319 & 0 & .5853816 \\
PhDs $\left.{ }^{*}\right)$ & .254427 & .2900657 & 0 & 1 \\
int_R\&D & .9017857 & .2989417 & 0 & 1 \\
firm_innov_effort & 52069.72 & 71839.91 & 0 & 581847.7 \\
gdp_prov ${ }^{(* *)}$ & 28.20955 & 2.993663 & 18.94 & 30.23 \\
firm_industry_low & .0357143 & .1864109 & 0 & 1 \\
firm_industry_mlow & 0 & 0 & 0 & 0 \\
firm_industry_mhigh & .0267857 & .1621823 & 0 & 1 \\
firm_industry_kis & .7589286 & .429656 & 0 & 1 \\
firm_industry_nkis & .0714286 & .2586969 & 0 & 1 \\
firm_industry_restact & .0178571 & .1330273 & 0 & 1 \\
firm_costobst & .5673622 & .2087513 & .25 & 1 \\
firm_infobst & .3866511 & .1276362 & .25 & 1 \\
\hline (*) 101 observations. & & & & \\
(**) thousands. & & & & \\
& & & &
\end{tabular}


Table A2. Descriptive statistics for Mixed Parks (206 observations).

\begin{tabular}{|c|c|c|c|c|}
\hline Variable & Mean & Std.Dev. & Min & Max \\
\hline \multicolumn{5}{|l|}{ Dependent Variables } \\
\hline new_prod & 19239.16 & 57624.3 & 0 & 542121 \\
\hline patnuml & 309.9504 & 1222.031 & 0 & 14285.71 \\
\hline coop_uni & .407767 & .4926166 & 0 & 1 \\
\hline RDboughtl & 946.8914 & 3249.854 & 0 & 30000 \\
\hline \multicolumn{5}{|c|}{ Independent variables - STPs' characteristics } \\
\hline park_age & 19.41748 & 4.815674 & 8 & 24 \\
\hline park_firms & 206.5485 & 102.1768 & 30 & 336 \\
\hline park_staff & 14.98841 & 24.28875 & 7.738095 & 116.6667 \\
\hline park_services_i & .8883495 & .3157032 & 0 & 1 \\
\hline park_services_c & .1796117 & .3847988 & 0 & 1 \\
\hline \multicolumn{5}{|c|}{ Control variables - firms' characteristics } \\
\hline firm_age & 11.4466 & 10.08958 & 1 & 64 \\
\hline firm_sales & 9867963 & $3.14 \mathrm{e}+07$ & 0 & $3.31 \mathrm{e}+08$ \\
\hline firm_exports & .0278694 & .1086076 & 0 & .7647692 \\
\hline $\mathrm{PhDs}^{-(*)}$ & .141093 & .2355709 & 0 & 1 \\
\hline int_R\&D & .8106796 & .3927173 & 0 & 1 \\
\hline firm_innov_effort & 42728.68 & 105366.6 & 0 & 915000 \\
\hline gdp_prov ${ }^{(* *)}$ & 23.28442 & 6.248539 & 17.08 & 30.34 \\
\hline firm_industry_low & .0194175 & .1383232 & 0 & 1 \\
\hline firm_industry_mlow & .0194175 & .1383232 & 0 & 1 \\
\hline firm_industry_mhigh & .0728155 & .2604664 & 0 & 1 \\
\hline firm_industry_kis & .6747573 & .4696067 & 0 & 1 \\
\hline firm_industry_nkis & .1019417 & .3033088 & 0 & 1 \\
\hline firm_industry_restact & .0485437 & .2154356 & 0 & 1 \\
\hline firm_costobst & .5447968 & .1980654 & .25 & 1 \\
\hline firm_infobst & .3911716 & .1179434 & .25 & .8 \\
\hline
\end{tabular}


Table A3. Descriptive statistics for Technology Parks with University (260 observations).

\begin{tabular}{lllll}
\hline Variable & Mean & Std.Dev. & Min & Max \\
\hline Dependent Variables & & & & \\
\hline new_prod & 13062.02 & 34082.59 & 0 & 290812.7 \\
patnuml & 462.365 & 1667.769 & 0 & 13333.33 \\
coop_uni & .3384615 & .474099 & 0 & 1 \\
RDboughtl & 622.1162 & 2123.337 & 0 & 15000 \\
\hline Independent variables - STPs' characteristics & & \\
\hline park_age & 15.91154 & 3.638578 & 7 & 22 \\
park_firms & 290.4192 & 328.0653 & 15 & 1436 \\
park_staff & 14.40331 & 12.48315 & 2.715878 & 68.75 \\
park_services_i & .4230769 & .4950002 & 0 & 1 \\
park_services_c & .0769231 & .2669833 & 0 & 1 \\
\hline Control variables -firms' characteristics & & \\
\hline firm_age & 13.06538 & 12.32411 & 1 & 89 \\
firm_sales & $1.24 \mathrm{e}+07$ & $5.33 \mathrm{e}+07$ & 0 & $6.84 \mathrm{e}+08$ \\
firm_exports & .0389088 & .1292199 & 0 & .8 \\
PhDs $\left.{ }^{*}\right)$ & .0823416 & .1757204 & 0 & 1 \\
int_R\&D & .8192308 & .3855691 & 0 & 1 \\
firm_innov_effort & 27853.12 & 49005.91 & 0 & 551461.5 \\
gdp_prov ${ }^{(*)}$ & 24.95604 & 5.025551 & 17.89 & 31.38 \\
firm_industry_low & .0269231 & .1621708 & 0 & 1 \\
firm_industry_mlow & .0423077 & .2016784 & 0 & 1 \\
firm_industry_mhigh & .0653846 & .2476801 & 0 & 1 \\
firm_industry_kis & .6653846 & .4727659 & 0 & 1 \\
firm_industry_nkis & .0730769 & .2607647 & 0 & 1 \\
firm_industry_restact & .0384615 & .1926786 & 0 & 1 \\
firm_costobst & .5509438 & .197088 & .25 & 1 \\
firm_infobst & .398087 & .132639 & .25 & 1 \\
\hline${ }^{* *}$ 213 observations. & & & & \\
(*) $^{*}$ thousands. & & & &
\end{tabular}


Table A4. Descriptive statistics for Pure Technology Parks (271 observations)

\begin{tabular}{lllll}
\hline Variable & Mean & Std. Dev. & Min & Max \\
\hline Dependent Variables & & & & \\
\hline new_prod & 14691.47 & 46605.63 & 0 & 607684.4 \\
patnuml & 408.9418 & 1618.174 & 0 & 12000 \\
coop_uni & .2878229 & .4535858 & 0 & 1 \\
RDboughtl & 379.5431 & 1464.231 & 0 & 12800 \\
\hline Independent variables - STPS' characteristics & & \\
\hline park_age & 15.11439 & 4.559668 & 6 & 19 \\
park_firms & 205.262 & 170.4959 & 25 & 430 \\
park_staff & 23.23026 & 17.93033 & 0 & 62.80992 \\
park_services_i & .5571956 & .4976369 & 0 & 1 \\
park_services_c & .2619926 & .4405322 & 0 & 1 \\
\hline Control variables - firms'characteristics & & \\
\hline firm_age & 14.58672 & 13.83336 & 1 & 152 \\
firm_sales & $1.81 \mathrm{e}+07$ & $8.16 \mathrm{e}+07$ & 0 & $8.68 \mathrm{e}+08$ \\
firm_exports & .0367454 & .1320954 & 0 & .9519433 \\
PhDs ${ }^{(*)}$ & .0783154 & .1840451 & 0 & 1 \\
int_R\&D & .6863469 & .4648356 & 0 & 1 \\
firm_innov_effort & 22280.33 & 36936.75 & 0 & 304282.4 \\
gdp_prov ${ }^{(*)}$ & 24.3783 & 4.998281 & 20.21 & 34.49 \\
firm_industry_low & .0590406 & .2361367 & 0 & 1 \\
firm_industry_mlow & .0516605 & .2217502 & 0 & 1 \\
firm_industry_mhigh & .1180812 & .3233013 & 0 & 1 \\
firm_industry_kis & .5535055 & .4980487 & 0 & 1 \\
firm_industry_nkis & .103321 & .3049409 & 0 & 1 \\
firm_industry_restact & .0516605 & .2217502 & 0 & 1 \\
firm_costobst & .5490226 & .2125276 & .25 & 1 \\
firm_infobst & .3955471 & .1275556 & .25 & 1 \\
\hline (*) 186 observations. & \multicolumn{5}{l}{} & \\
${ }^{* * *}$ thousands. & & & &
\end{tabular}

